This is the accepted version of this paper. The version of record is available at https://doi.org/10.1680/jensu.19.00036 


\section{UAE's Commitment Towards UN Sustainable Development Goals}

Tariq Umar PhD, CEng IntPE (UK), MICE (corresponding author)

Lecturer Civil Engineering, College of Engineering, A'Sharqiyah University, Oman.

E-mail: tariqumar1984@gmail.com

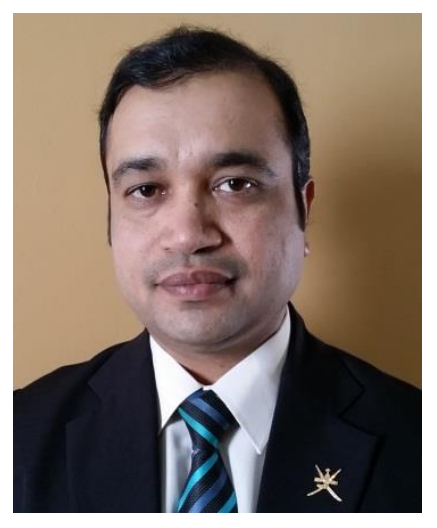

Charles Egbu PhD, FRICS, FCIOB, FAPM, FRSA, FHEA

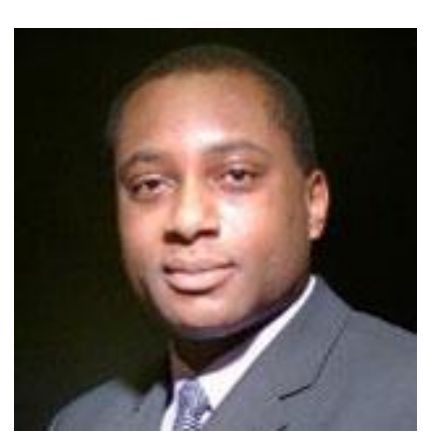

Pro-Vice Chancellor (Education and Experience), University of East London, UK.

George Ofori BSc, MSc, Ph.D, FCIOB, FRICS, FSPM Dean, School of The Built Environment and Architecture, London South Bank University, UK.

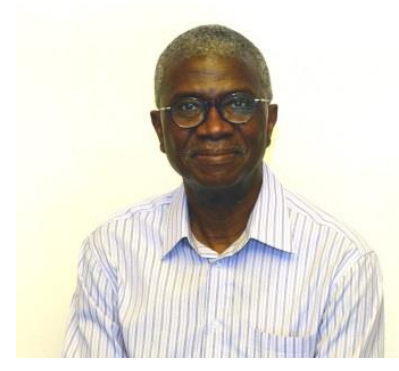


Mohamed Shaik Honnurvali M-Tech, MIET

Lecturer Electronic and Communication, College of Engineering, A'Sharqiyah University, Oman.

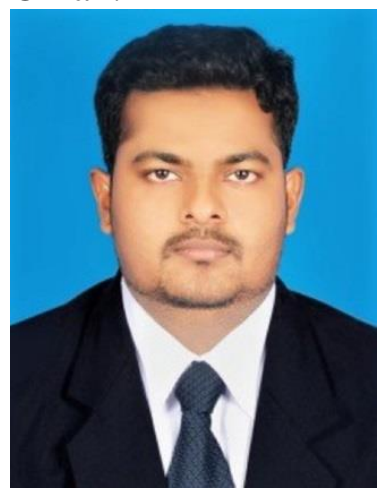

Messaoud Saidani BEng, PhD, PgCertLT, CEng, MIStructE

Associate Professor and Head of Research, School of Energy, Construction and Environment Faculty of Engineering, Environment and Computing,

Coventry University, UK.

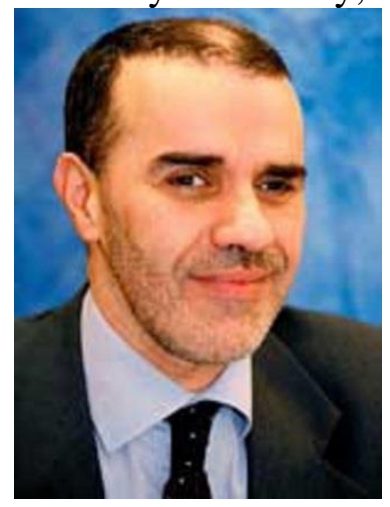


Abdussalam Shibani HND .BSc. MSc. PhD, PgCertLT, FHEA, MCMI, MAPM, ICIOB, PCQI Assistant Professor Construction and Project Management

School of Energy, Construction and Environment

Faculty of Engineering, Environment \& Computing

Coventry University, UK.

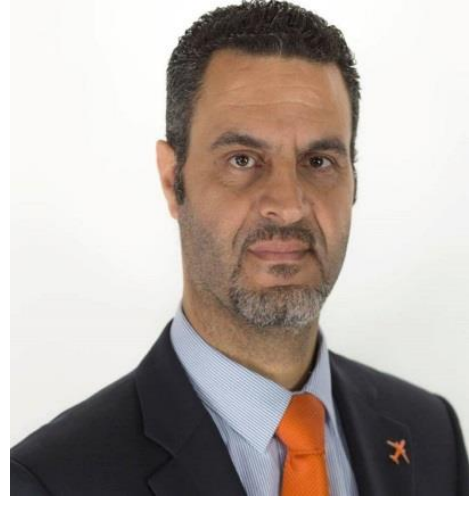

Alex Opoku BSc Hons, MSc, PhD, FHEA, MCIOB, MRICS

Associate Professor in Project Management and Quantity Surveying

The Bartlett School of Construction \& Project Management

Faculty of the Built Environment, University College London, UK.

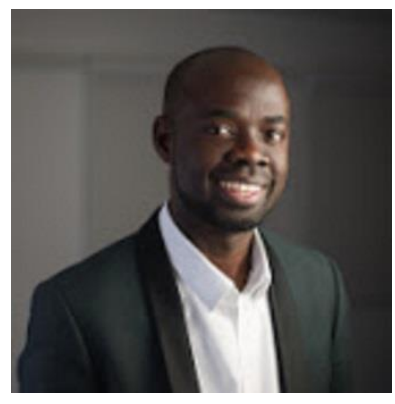

Naren Gupta DTSc, MTech, MBA, PhD, CEng, FIEE, MIRSE, SMIEEE, FHEA

Professor, Engineering and Built environment, Edinburgh Napier University, Edinburgh, UK.

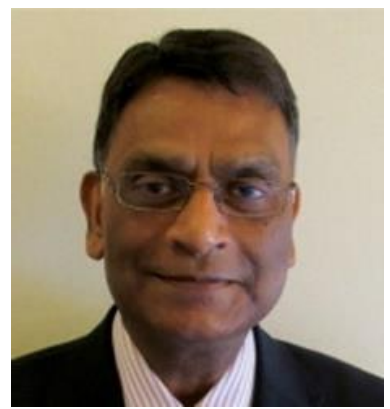


Dr. Keng Goh B.Eng (Honours), MBA, PhD, CEng MIET, FHEA

Lecturer, Engineering and Built environment, Edinburgh Napier University, Edinburgh, UK.

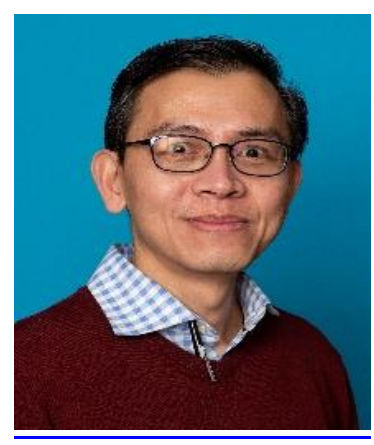




\section{Abstract:}

In 2015, the United Nations (UN) member countries, upon mutual understanding have identified 17 Sustainable Development Goals (SDGs), to be achieved by 2030. According to several reports, some countries are reflecting good progress but overall, no country is on track towards achieving all the UN SDGs. This article aims to show the progress and commitment of the United Arab Emirates towards UN SDGs. A qualitative research approach using a systematic literature review following PRISMA compliance and a semi-structured interview was adapted to achieve the aim of this research. The results reflect that Emirates has achieved only one goal. Most of the remaining goals are not on track to be achieved by 2030. In fact, some of the goals related to Energy and Climate are getting more riskier. The country under its different initiatives aims to invest a total of US \$ 163.35 billion in different projects that target to achieve $50 \%$ clean energy by 2050. It is, however, not clear from the government strategy that how these targets will be achieved. Similarly, the government needs to ensure a close relationship between organizations so that the action of one unit doesn't derail the plans of other organizations.

Key Words: Sustainability, Environment, Fossil fuels, Renewable Energy, Climate change.

\section{Introduction:}

The approach of sustainability first truly appeared in the Brundtland Commission Report, published in 1987. This report was submitted to the UN 42 ${ }^{\text {nd }}$ General Assembly session. This report truly aimed to warn the countries about the negative environmental impact caused by economic development and globalization. The report further aimed to provide solutions to the problems arising from industrialization, urbanization and population growth (Brundtland Commission, 1987). The idea of sustainability developed in the early 1980s as reported in the International Geosphere-Biosphere Programme can be defined as "meeting fundamental human needs while preserving the earth natural environment" (IGBP, 1999). Since the earth's population is increasing, it is putting pressure on the earth's resources. According to the World Economic Forum, it is estimated that food production will need to double by 2050 to feed 10 billion people on the earth (WEF, 2018). Today, sustainability has three essential pillars including environmental protection, social development, and economic growth and sustainable development can be been defined as a development that meets the needs of the present without compromising the ability of future generations to meet their own needs (Sachs, 2015). The need for sustainable development is truly recognized by all countries and thus in 2015; the UN is able to introduce seventeen SDGs to be achieved by 2030 (UN-SDG, 2015). These goals along with its target and leading indicators that help to assess the progress of each goal are summarized in appendix 1. Most of the UN SDGs are closed to the engineering profession or in other words, the engineering profession and community have a wider role to achieve these goals. Many professional engineering organizations have already incorporated the requirement of sustainable development in professional engineering practices (Cruickshank and Fenner, 2007; Head, 2009). For instance, in 1994, the American Association of Engineering Societies issued a statement 
titled "The Role of the Engineer in Sustainable Development" which proclaimed that sustainable development requires "dramatic changes in the culture of engineering (McIsaac and Morey, 1998). Similarly, the Institution of Civil Engineers in the United Kingdom has incorporated the 'Sustainable Development' as one of the attributes which need is mandatory for Chartered Engineer registration. Under this attribute, the candidate required to demonstrate, (i) a sound knowledge of best practice in sustainable development, (ii) manage engineering activities in a way that contributes to sustainable development and (iii) lead continuous improvement in sustainable development (ICE member attributes, 2019).

There has been some significant progress on the UN SDGs made globally as reflected in the SDGs Report for 2018, however, some commitment towards some goals has also been dropped which may have an impact on the overall achievement by 2030 on those specific goals (TSDGR, 2018). For instance, some goals and indicators reflect good progress at a specific country level. For example, in the United States, the annual mean level of fine particulate matter (PM2.5) dropped to 9 micrograms per cubic meter, which was 15.7 micrograms per cubic meter in 2016 (EPA, 2017). On the other hand, the performance of some goals and their indicators has dropped down when compared at the global level. For instance, the progress of the goal 6, which aims to "ensure availability and sustainable management of water and sanitation for all" reflect that the funding commitments to the water sector dropped by more than 25\% from 2012 to 2016. Similarly, the progress of the Goal 11, which is related to sustainable cities and communities, reflect that between 2000 and 2014, the proportion of the world's urban population living in slums declined by $20 \%$ (from 28.4 to $22.8 \%$ ). However, the rate of new home construction lagged far behind the rate of urban population growth, and the number of people living in slums actually increased from 807 million to 883 million over this period. The majority of those living in slums are located in three regions: Eastern and South-Eastern Asia (332 million), Central and Southern Asia (197 million) and sub-Saharan Africa (189 million). Similarly, Data from 214 cities or municipalities in 103 countries show that about three-quarters of municipal solid waste generated is collected (figure 1). In sub-Saharan Africa, less than half of all municipal solid waste generated is collected, with adverse effects on the health of residents. Moreover, even when waste is collected, it is often not treated and disposed of in a sustainable and environmentally sound manner. Managing such waste continues to be a major challenge facing urban areas in several regions. Considering the example of the main city (Dubai) of the Emirates, the World Bank data reveals that the total municipal solid waste generated in one year in this city is 2,689,808 tonnes/year (WB, 2019). Municipal solid waste is one part of the total waste, the actual waste generated in Dubai could be several times more than municipal solid waste. The data further reveals that only $25 \%$ of municipal solid waste in Dubai is recycled, which represent a small portion of the total waste generated in Dubai.

Considering the three main sustainability pillars, the performance of the Emirates in different areas is not at a satisfactory level. For instance, electricity consumption in the Emirates has increased from $681.162 \mathrm{kWh}$ per capita in 1971 to $11,088.35 \mathrm{kWh}$ per capita in 2014 (IEA, 
2014). This sharp increase in the consumption could be justified considering the reasons that now many peoples have access to electricity and there are now many new industrials units that are now run by electricity, however, the country still depends on the conventional resources such as oil, gas, and coal to produce electricity (IEA, 2016). The current $\mathrm{CO}_{2}$ emission in Emirates is quite high. For instance, the $\mathrm{CO}_{2}$ emission in Sweden is 4.478 tonnes per capita, while in Emirates it stands at 22.94 tonnes per capita (CDIAC, 2017). The high levels of electricity consumption and greenhouse gas emission have also affected the Emirates' air quality. The current value of the atmospheric particulate matter (PM2.5) in Emirates is 40.91 micrograms per cubic meter while the same value in Denmark is 10.03 micrograms per cubic meter only (Cohen et al., 2017). Such air quality can highly affect the health of the Emirates population. The world Health Orgaznaition (WHO, 2018) guidelines on air quality recommend a value of 10 micrograms per cubic meter for PM2.5. The current value of PM2.5 in Emirates is four times more than the recommended values. There are still challenges in the Gulf Cooperation Council (GCC) countries to adopt the available renewable energy resources to meet some of its electricity requirements. These challenges are associated with policies and regulations, manpower experience and competencies, renewable energy education, public awareness, costs and incentive for renewable energy, and government commitment (Umar et al., 2019-a). The construction industry in most of the GCC countries is at a peak as the region is improving its infrastructures (Umar, 2017-a; Umar et al., 2019-b). The current capacity of Emirates cement production stands at 40.7 million tonnes, which is double than its own requirement. This extra cement is normally exported to the countries including, Oman, Egypt, and some countries in Africa (BBB, 2015). While cement is the best bonding material and it also helps to sustain the Emirates industry and economy, at the same time it is not environment-friendly. According to the estimate presented by Umar et al., (2019-c), one tonne of cement produces the same amount of $\mathrm{CO}_{2}$. Similarly, the construction waste in Emirates is accounted for almost $70 \%$ of the total solid waste generated in the country (Swain, 2018). Such waste is simply dumped in different dumpsite or landfill stations which increase the greenhouse gas emission and create environmental issues (Umar et al., 2019d). To achieve the UN SDGs related to energy and sustainable production and consumption, emirates seriously need to focus on the issue related to the construction industry. Overall, the situation over the GCC countries is not much different from each, the next section, therefore, provides an overview of the GCC region in relation to different UN SDGs. 


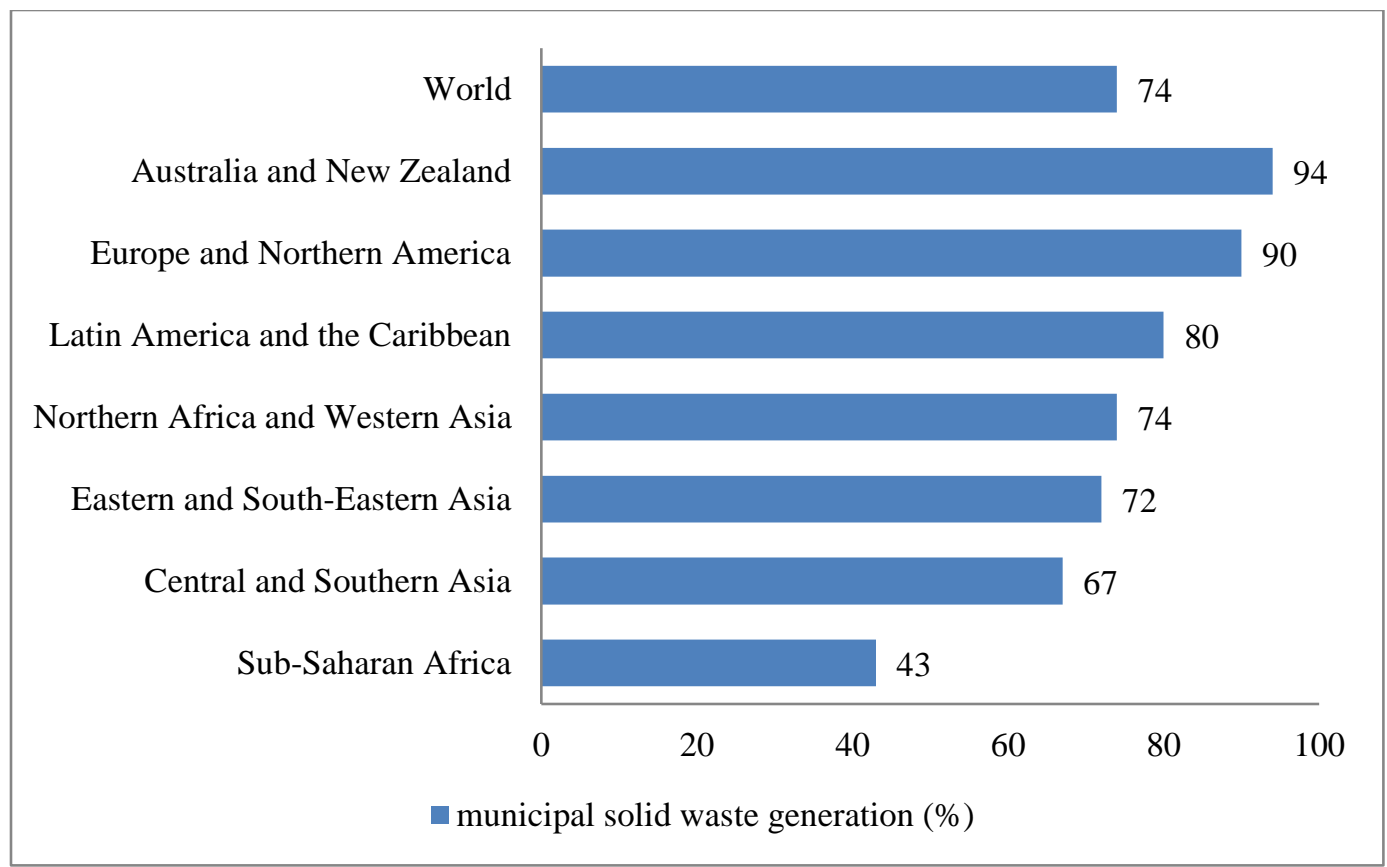

Figure 1: Proportion of the municipal solid waste generated that is collected, 2001-2015 (data from 214 cities/municipalities in 103 countries) - (Based on TSDGR, 2018)

\subsection{An Overview of the GCC Region:}

According to the SDG Index and Dashboards Report, no country is on track towards achieving all the UN SDGs while countries with conflicts are experiencing the sharpest reversals in their progress (SDGIDR, 2018). At the outlook of the Gulf countries, they are normally recognized as high consumer of the earth resources and as the main contributor to $\mathrm{CO}_{2}$ emission, and their low progress towards SDGs, however, some countries in gulf region have recently demonstrated their commitment towards these goals (Salahuddin and Gow, 2014; UAESDG, 2019). In relation to high consumption of natural resources, a study conducted by Umar and Wamuziri (2016), while exploring the wind and solar energy resources in Oman, particularly noted that energy consumption in GCC (Gulf Cooperation Council) is more than the double of the consumption in China and United Kingdom. Due to the high level of energy consumption, the average $\mathrm{CO}_{2}$ emission per capita is GCC countries is (=25.36 Tonne) is three times greater than the $\mathrm{CO}_{2}$ emission per capita in China ( $=7.5$ Tonne) and almost four times greater than the $\mathrm{CO}_{2}$ emission per capita in United Kingdom (=6.5 Tonne) - figure 2. Some research studies noted that much of the electricity in Oman is produced from oil and gas, which are neither renewable nor sustainable therefore these studies explore the geothermal, and biomass and solar resources for electricity production in Oman (Honnur Vali et al., 2018; Umar, 2018-a; Umar, 2018-b; Umar, 2017-b; Honnurvali et al., 2018). On the other side, countries such as the United Kingdom have raised the percentage (\%) of the total energy consumption from renewable sources to $8.6 \%$ which was only $1.3 \%$ in 2000 (ONS, 2017). The global commitment towards sustainable energy is well demonstrated by Umar and Egbu (208-a), however, they also noted that GCC countries 
have not yet submitted their intended action plan required under the UN Framework Convention on Climate Change (UNFCC, 1992). The UN under Goal 7 aims to reduce the adverse per capita environmental impact of cities, including paying special attention to air quality and municipal and other waste management. In relation to this goal, the overall gulf region's progress is, however not satisfactory. The annual solid waste generation in the Gulf region has exceeded 150 million tonnes. GCC countries including Saudi Arabia, Kuwait, United Arab Emirates, Qatar, and Bahrain featuring among the world's top ten per capita waste generators (figure 3). Lack of legal and institutional frameworks has been a major stumbling block in the progress of the waste management sector (Zafar, 2018). The per capita production of municipal waste in top GCC cities, such as Riyadh, Doha, Abu Dhabi, and Dubai, is more than $1.5 \mathrm{~kg}$ per day which is among the highest worldwide (Zyoud et al., 2015). Across the region, the recycling sector is underdeveloped and hardly 10-15 percent of the waste is recycled (Zafar, 2015).

The above discussion clearly reveals that GCC countries' progress towards UN SDGs could be comparatively slow. This article, therefore, aims to explore the current progress of the region using a qualitative research approach. The progress of the United Arab Emirates which is one of the modern and advanced member countries of the GCC is reported in this article. Although each year the report issued by the UN provides an overall review of the SDGs in a global context, this paper explores the progress of Emirates, rich in oil and gas reserves, towards UN SDGs. This insight is not only helping to understand the Emirates' progress and commitment towards these goals but also helps to understand the GCC region's overall situation in relation to UN SDGs. The semi-structured interview held with the engineering professionals in the country explains the thought of the engineering community and highlight the challenges being faced by these respondents in the area of sustainability.

The next section of the article explains the research methodology adopted in this research. 


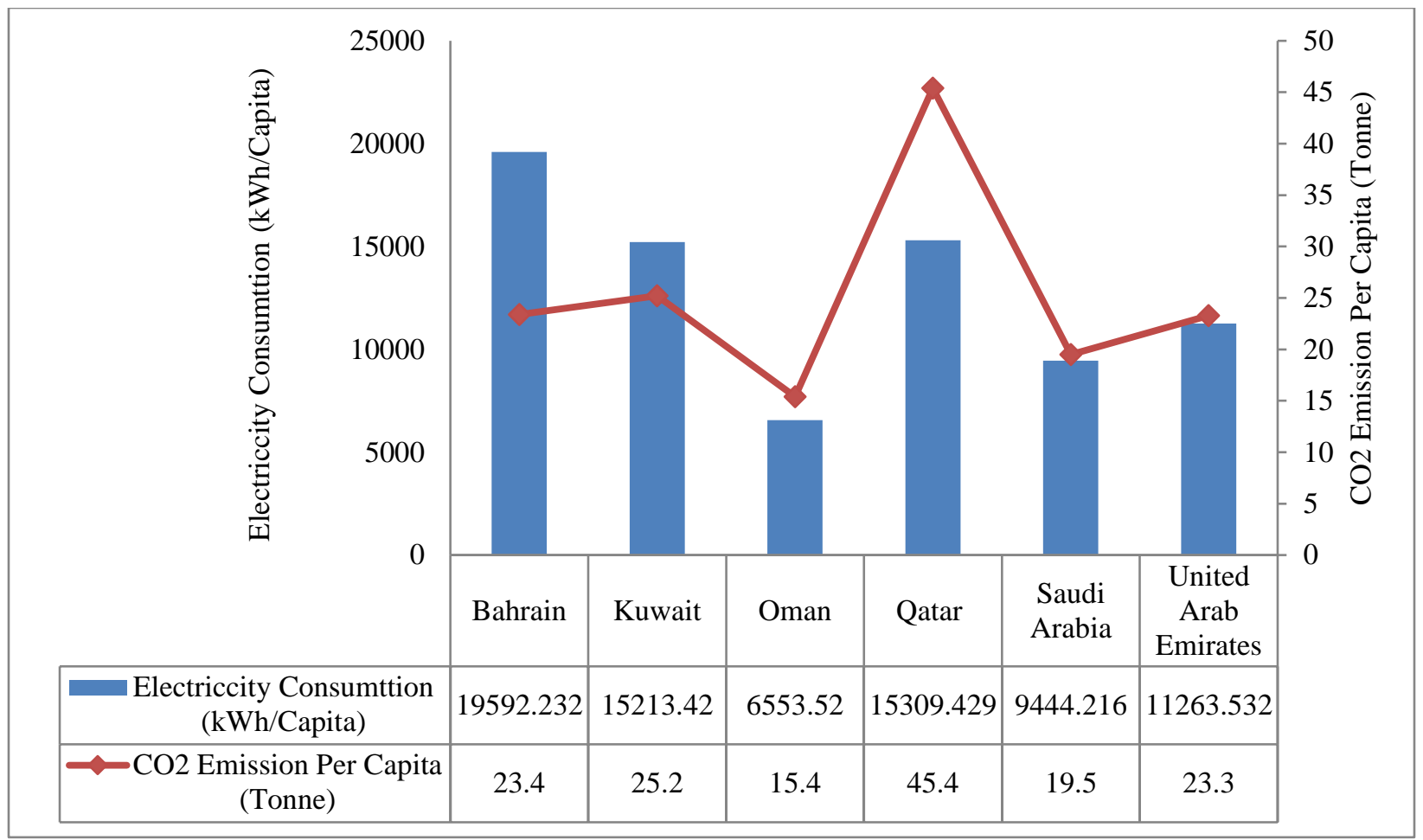

Figure 2: Electricity Consumption and $\mathrm{CO}_{2}$ Emission Per Capita in Selected GCC Countries (Based on WB, 2014-a, WB, 2014-b)

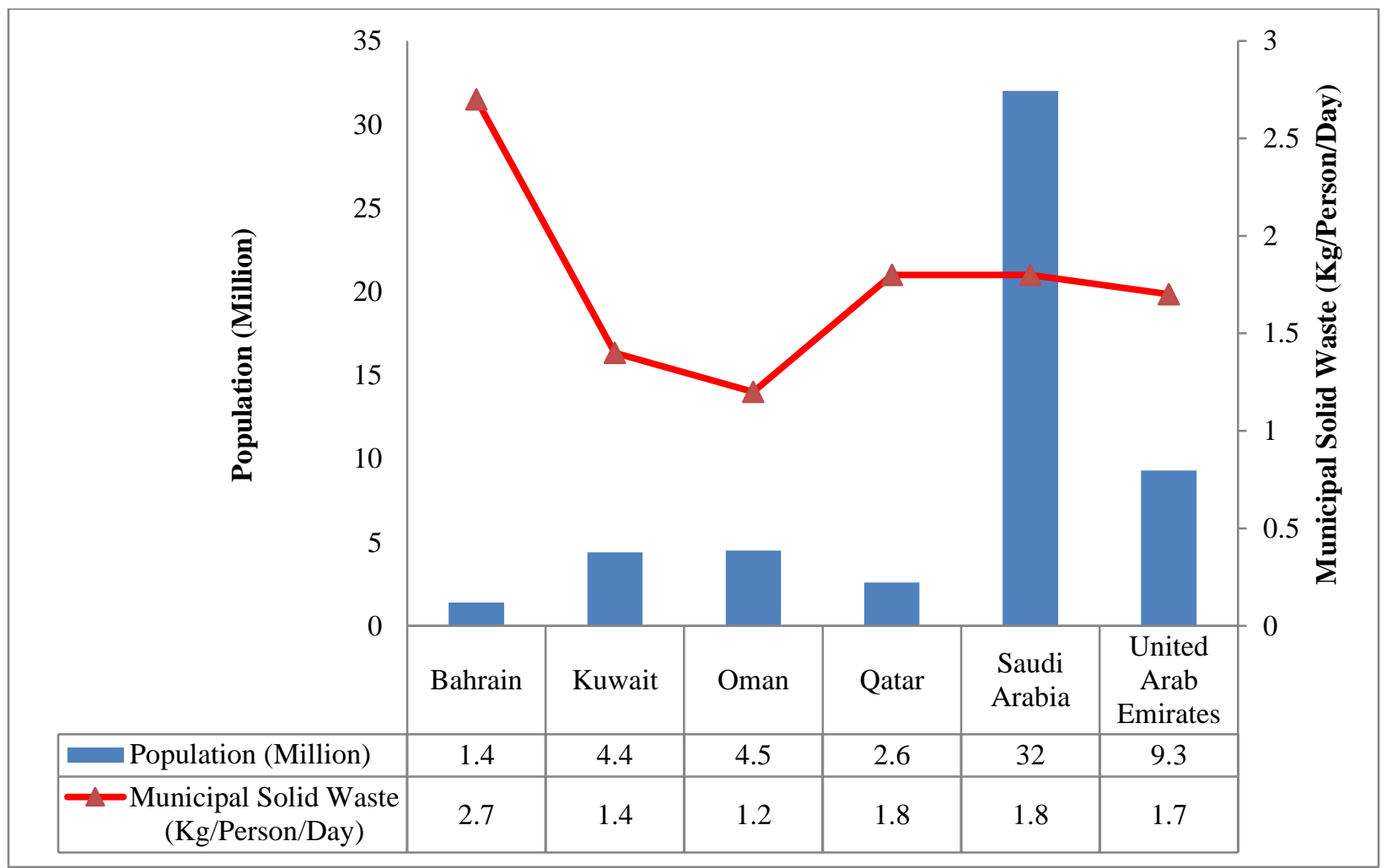


Figure 3: GCC Population VS Municipal Waste Generation (Based on Zafar, 2018)

\section{Research Methodology:}

The main aim of this research was to explore the progress of the GCC region towards the achievement of the UN SDGs. Apart from this, the paper also aimed to find the perspective of the engineering professionals on the challenges and opportunities involved in the SDGs. This was accomplished using a qualitative research method as opposed to a quantitative method. Concisely, the difference between these two research methods is given below (Bryman, 2016). Quantitative research stresses quantification in data collection and examination. It takes a deducible way to the connection among theory and research and stress are kept on the confirmation of theories. The quantitative research method integrates the norms and practices of the natural scientific model and positivism. It views social phenomena as an outer objective truth (Cooper et al., 2006). On the other side, a qualitative research approach stresses on words and contexts despite quantification in data collection (Opdenakker, 2006). It stresses an introductory approach in the relationship between theory and research and focus is settled on the formation of theories. The majority of the researchers prefer to incorporate both qualitative and qualitative methods, referred to as combined research methods and highly appreciated in the literature due to certain advantages (Umar and Egbu, 2018-b). Since the research presented in this paper is exploratory in nature, a qualitative method consists of a systematic literature review and a semistructured interview was considered as the most suitable method to collect the data.

To collect the relevant data, an internet search was employed. Since the UN SDGs were adopted in 2015, therefore the search period was kept from 2015 to 2019. Two of the major databases including Scopus and Web of Science were taken on board. Apart from these databases, google search engine was also used to search the relevant report published by local or international organizations. Different keywords such as "UN SDGs", "UAE SDGs", "Sustainability in Emirates" and "Sustainability Progress in UAE" were used for the search purpose. For each keyword, the first 25 items were considered to be further refined using the screening process. This approach was however only applied to the results obtained from the Google search engine. The approach was adopted due to the fact that in most cases the search engines such as Google provide a large number of the result. It is almost not possible to consider such a large number in any study. Thus, it was considered reasonable that for each item, the first 25 results will be used for further screening.

To ensure that a systematic review process is adopted in this study, the research method for the review was guided by Preferred Reporting Items for Systematic Reviews and Meta-Analyses (PRISMA). The PRISMA guidelines required to follow a four steps process to include the final of studies in the systematic review and meta-analysis (Moher et al., 2009). The data and documents found in the search were screened using different screening criteria. The criteria for the research paper were that it should be written in English and the keywords should be in the title, abstract or in the keywords section. For the various reports obtained from the google search engine, the criteria were that it should be published or created by a legitimate source and should 
be relevant to the United Arab Emirates' sustainability progress. All the relevant information either published as a document or as a web page was considered provided that they pass the screening process. Using this criterion, all the data and publications available from the government organizations, ministries, independent government entities, independent nongovernment organizations and research publications relevant to the area of the study were considered. Considering the scope of the work and keeping in mind that the different databases and search engine like Google may result into a large volume of the documents, which could be difficult to screen, the selection of the items were only kept to the first 25 documents from each keyword and search engine. This criterion was, however, not applied to the search obtained from the Scopus and Web of Science. Descriptive analysis was conducted to compare the Emirates' progress with other countries both at the global level and regional level.

For the semi-structured interview, a set of questions was developed and validated on a relatively small sample. The purpose of this exercise is to find the thoughts of the engineering community on SDGs working in Emirates. The criteria for selecting the respondents were set as the participants should have at least 15 years of experience in Emirates and should have sufficient knowledge and experience of engineering sustainability practice at a local context. Only the participants with academic background and experience background of Civil and Environmental engineering were considered for this purpose. A similar approach was also adopted by Umar et al., (2019) for selecting the respondents for a study related to renewable energy in the GCC region. To search the relevant respondents, their profile was searched and screened using their organization's websites. The organization's name and websites were obtained from the UAE contractors Association website (UAE-CA, 2019). Personal links, connections, LinkedIn and WhatsApp groups were also used to identify suitable candidates for this interview. Finally, a list of 20 respondents was developed. A study conducted by Umar (2019) noted that the sample size for most of the research studies involves semi-structured interviews that are roughly equal to 20 . The respondents were contacted through emails asking for their cooperation in the study. A total of 10 respondents made themselves available for the interview. All the participants in this interview were male. The interview was conducted telephonically. Although the number of participants in this interview was comparatively low, however, there are a number of examples wherein such exploratory studies were conducted with much smaller respondents (Umar, 2018-c; Umar and Egbu, 2018-c). The interview questions are appended in Appendix II.

The next section of the paper provides the result and discussion derived from the adopted research methodology.

\section{Results and discussion:}

When the first term "UAE SDGs" was used in the Google search engine, it has given a total search result of 4,090,000. Similarly, the term "Sustainability in Emirates" has given a total search result of $47,600,000$. The last term "Sustainability Progress in UAE" provided a total search result of 5,480,000. The first 25 results of the Google search engine using the respective keywords were considered for further screening process (figure 4). The raw number of the result becomes $300(\mathrm{~N}=300)$ as explained in equation 1. At the first screening process stage, the duplicate items/records equal to 109 , were removed. Thus the eligible items/records for 
screening purposes were $191(\mathrm{~N}=191)$. At this stage, the screening criteria as described in the methodology section was applied, which resulted in the removal of 63 items/records $(\mathrm{N}=128)$. At the eligibility stage, a total of 65 items were considered not to be eligible for further consideration. Thus the final items/records left for the qualitative and quantitative analysis were, therefore, stood at $63(\mathrm{~N}=63)$. The United Arab Emirates' progress towards UN SDGs, extracted from these items/records $(\mathrm{N}=63)$ is highlighted in the next section.

The total number of records $(\mathrm{N})=$ Number of keywords $\times 25 \times 1+$ database results ..Equation 1.

Wherein;

Number of keywords $=4$

Databases results $=($ Scopus $=111$, Web of Science $=89 ;$ total $=111+89=200)$

Thus;

$\mathrm{N}=4 \times 25+200=300$ 


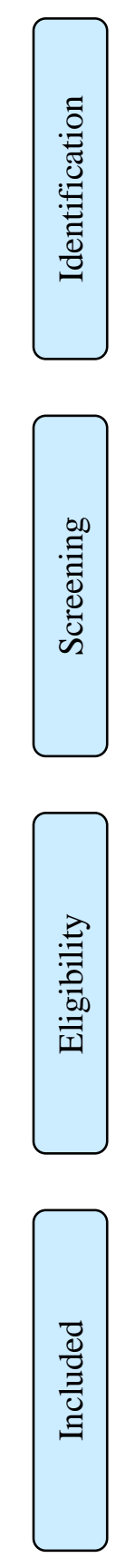

Items / Records Identified Through

Database Searching $(\mathrm{n}=57,170,000)$, record considered $(n=300)$
Additional Items / Records Identified Through Other Sources

$(\mathrm{n}=0)$
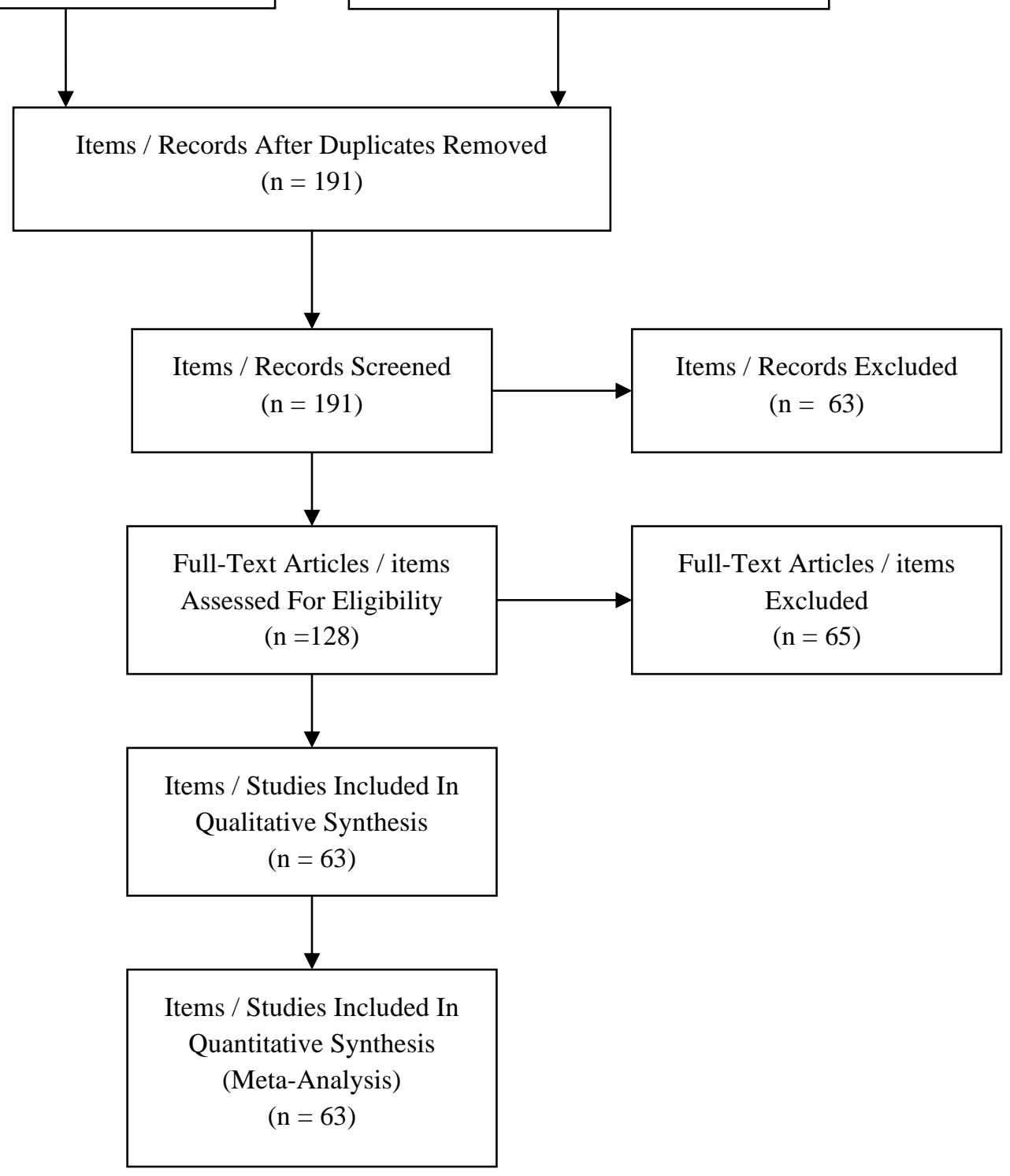
Figure 4: PRISMA Process Adopted in the Research

\subsection{Emirates' Progress Towards UN SDGs:}

The first progress report and ranking report on the UN SDGs issued in 2015, which considered the progress of 34 countries, indicates that there was no country in the list from the GCC region. This was due to the fact that there was limited or no data from this region to be considered in the report, and secondly, this report aimed to assess the rich countries that they are ready towards UN SDGs (Kroll, 2015). In the second global report and raking of UN SDGs, the United Arab Emirates was ranked 55 ${ }^{\text {th }}$ with a mean score of 63.6 (0 - 100) (Sachs et al., 2016). A total of 149 countries were considered in this ranking while a total of 44 countries were excluded from this ranking due to several reasons. Regionally, Qatar was placed on the top with a global ranking and score of 49 and 68.5 respectively. Bahrain was excluded from SDG Index and Dashboards due to insufficient data. Overall, at the regional level Emirates was able to secure the second position in the GCC region based on its global score and ranking (figure 5). The 2017 SDGs Index and Dashboards which considered a total of 157 countries around the world, ranked the United Arab Emirates at 77 with a total global index score of 66.0 (0 - 100) (Sachs et al., 2017). Overall the raking of the United Arab Emirates as compared with 2016 raking has been declined, however, at the same time the global index score of the country has increased from 63.6 to 66.0. Clearly, the ranking is declined due to the fact that in 2016, the number of countries which were considered in the raking was 149 , while in 2017 , this number was 157 . At the same time, this also reflects that some countries have achieved good progress compared with the United Arab Emirates. At the GCC region level, the United Arab Emirates, based on its global ranking and global index score, was able to take the first position from Qatar in 2017 as shown in figure 6. 


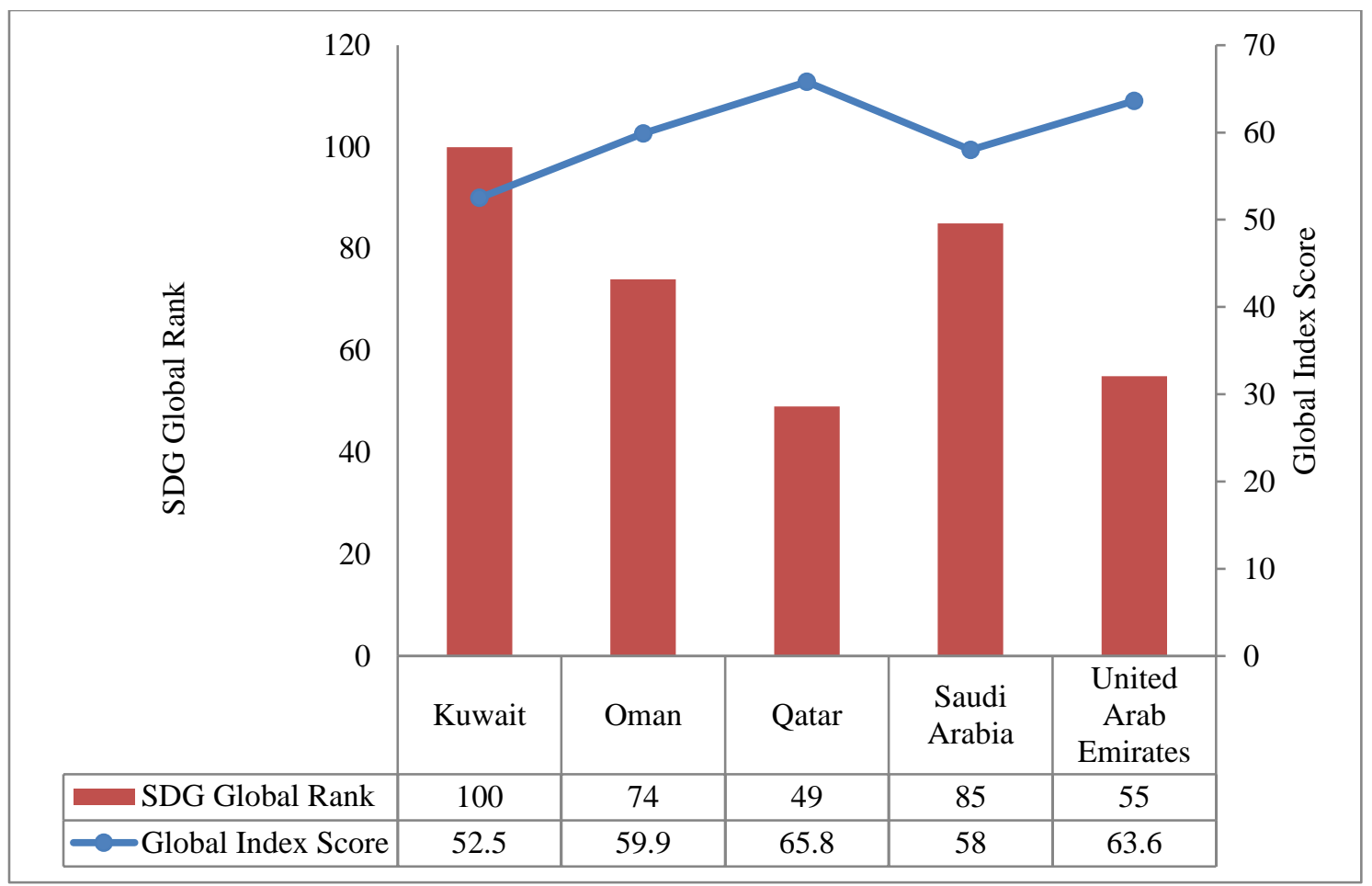

Figure 5: Global SDG Index and Ranking of GCC Countries (2016)

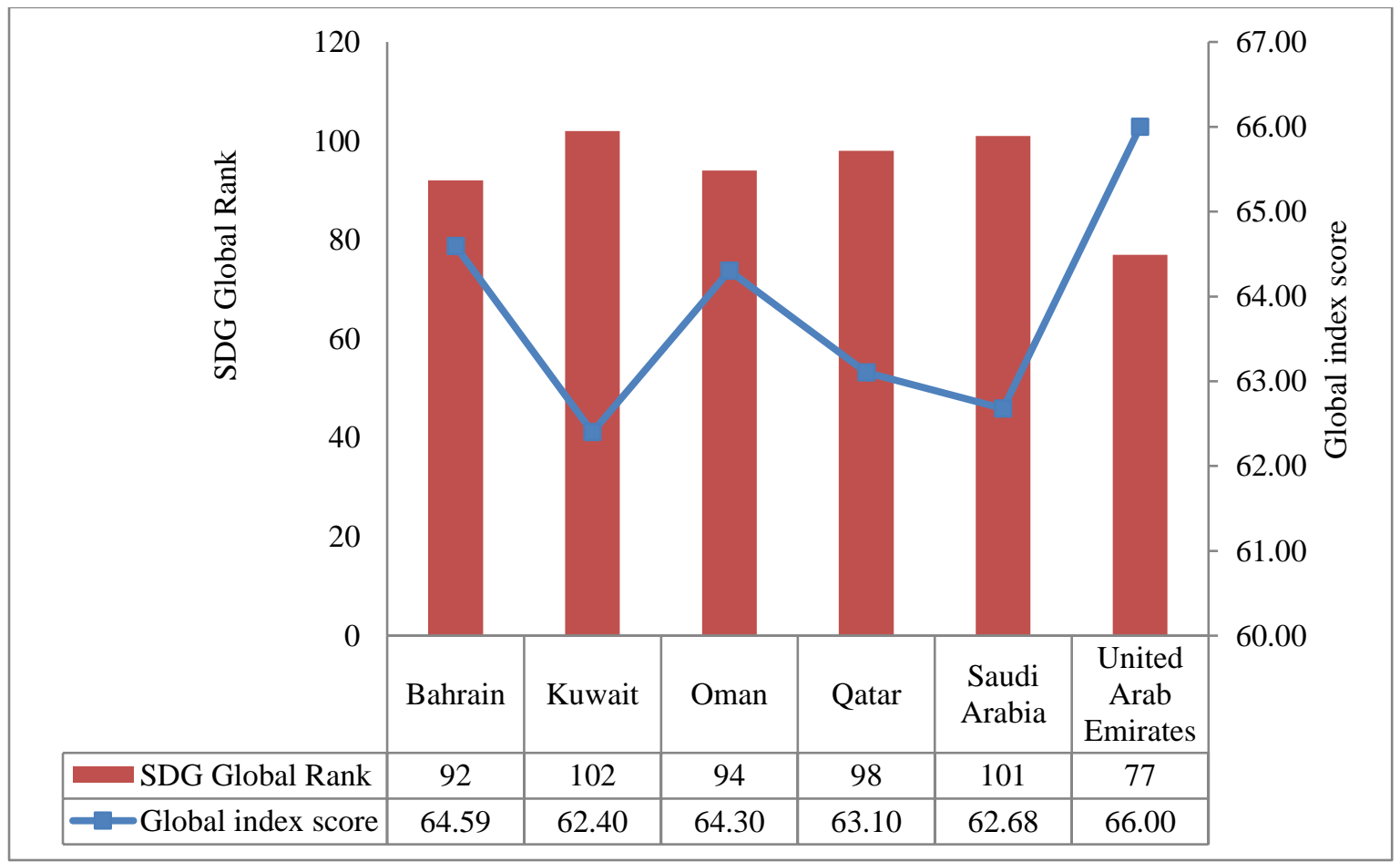

Figure 6: Global SDG Index and Ranking of GCC Countries (2017) 
The 2018 SDGs Index and Dashboards indicate that globally, the United Arab Emirates ranking stood at 60 with a global index score of $69.2(0-100)$. Both based on the global ranking and index score Emirates was leading the GCC region as shown in figure 7 (Sachs et al., 2018). Similarly, both the ranking and index score, as compared with the last year, has been improved which reflects that overall the country is on the track towards achieving the UN SDGs. The global index data shows that the score of the United Arab Emirates is gradually increasing which was 63.6 in 2016, 66.0 in 2017 and 69.2 in 2018. The mean index score of Emirates is the past three years was 66.26 on a scale of $0-100$. On average, there has been an improvement in the Emirates index score of $8.8 \%$ in the whole three years or $2.94 \%$ per year.

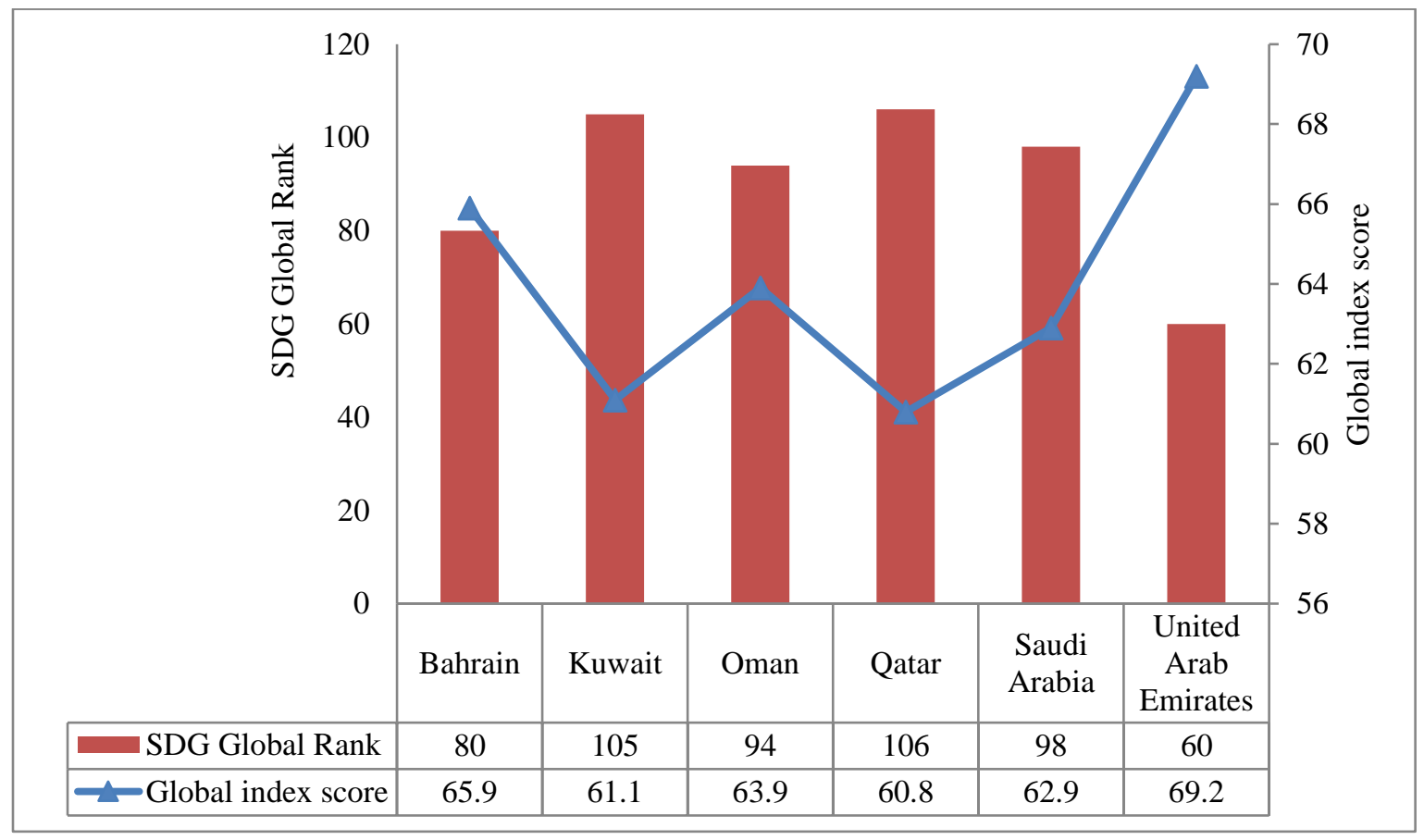

Figure 7: Global SDG Index and Ranking of GCC Countries (2017)

To effectively reflect the progress of the Emirates on each UN SDGs, the mean score of each seventeen goals are considered. The data reflects that the United Arab Emirates has already achieved Goal 1 (No Poverty, score $=100$ ) and further maintaining the same trend towards keeping this achievement. These results are based on Emirates citizens, however, more than $80 \%$ of the UAE population are foreigners and the conditions of these workers are always questionable (Strabac et al., 2018; WPR, 2019). In relation to Goal 1, Emirates, therefore, needs to focus on the foreign workers' conditions and needs to ensure that they have a safe and healthy working environment. There are a number of studies that reflect the wages of workers are based on their nationalities. In other words, western national workings in the UAE are getting more salaries than workers from Asian countries. Thus, in reality, considering the whole population of the Emirates, which includes Emiratis and foreigners, Goal 1 (No Poverty) is not yet achieved. 
Similarly, in relation to Goal 2, it is important to note that bio-capacity per person in the UAE which was 4.7 in 1980 has reduced to 0.6 in 2015. This has affected the ecological footprint and the value is increased from 6.5 (1980) to 9 (2015) (GFN, 2019). While the National Food Security Strategy aims to bring the country to the first position in the global food security index by 2051, which currently stood at $31^{\text {st }}$ position (NFSS, 2019; GFSI, 2018). When it comes to natural resources and resilience, Emirates currently stood at the last $\left(113^{\text {th }}\right)$ in the Global Food Security Index. The discussion reveals that Goal 2 (Zero Hunger) is at risk and thus serious efforts are required to achieve this goal in the due course of time.

As discussed in section 1, the atmospheric particulate matter in UAE is quite high that can affect the population health and can affect the achievement of Goal 3. Apart from this, the normal working hours for the private sector as per Article 65 of the UAE Labour Law are eight hours per day or 48 hours per week. The working hours per day can be increased up to 9 hours per day with the approval of the Ministry of Human Resources and Emiratization (UAE-Labour Law, 1980). The number of deaths in road accidents in the UAE is also quite alarming. The statistics published on the government website indicate that in 2016 there were 725 deaths, 560 major injuries, 3,110 medium injuries, and 3,011 minor injuries. The overall figure of road accidents causing deaths in 2015 was 675 while in 2016 it is rosed to 725 highlighting the importance of further improvement in making the highways more safer (Official Portal of the UAE Government, 2019). Similarly, foreigners' workers prior to employment required to undergoes a number of medical tests including HIV and AIDS screening, pulmonary tuberculosis, leprosy, and hepatitis (MHP, 2019).

As mentioned in table 1 significant challenges remain with Goal 4 (Quality Education) and the progress is insufficient to attain the Goal by 2030. As discussed by Jose and Chacko ( 2017) better allocation of government funding based on quality parameters and effective deployment of resources can lead to a better return on investment from the higher education sector. According to the Global Competitiveness Index Rankings, the overall quality of the UAE's primary and higher education has reduced in 2017-2018 has reduced as compared to 2016-2017 (PWC, 2018). A report on the cost of education in the UAE published by Hong Kong and Shanghai Banking Corporation (HSBC) noted that the school fees in the country are second highest in the world. The total cost of education from primary to university level is US\$ 99,378. Moreover, $65 \%$ of the parents in the UAE like send their children abroad to complete their studies (HSBC, 2017). The government, therefore, needs to take the required steps that can not only improve the quality of education but also reduce the cost.

There are major challenges that remain with Goal 5 (gender equality). The work carried out by Sachs et al. (2019) considered the progress of the Emirates on goal 5 as increasing at less than $50 \%$ of the required rate. The key indicators considered for this assessment were (i) demand for family planning satisfied by modern methods (\% women married, ages 15-49), (ii) female years of schooling (\% male), (iii) female labor force participation (\% male) and (iv) women in national parliaments (\%). The score of item three i.e. "female labor force participation" is particularly 
reducing and thus needs attention. Similarly, according to the Global Gender Gap Report for UAE stood at $121^{\text {st }}$ in a total of 149 countries. The report further ranked UAE $134^{\text {th }}$ for economic participation and opportunity, $95^{\text {th }}$ for educational attainment, $94^{\text {th }}$ for health and survival, and $68^{\text {th }}$ for political empowerment (WEF, 2018). Overall, it is necessary the government focus on this goal (Goal 5) as the achievement of this goal may accelerate the work on other goals.

Goal 6 (Clean Water and Sanitation) is among those Goals where UAE has significant challenges. The current approach of providing potable water may not be sustainable for a longer period due to the adverse effect of desalination. The study carried out by Bashitialshaaer et al., (2011) on the future salinity caused by desalination noted that the brine discharge in the Arabian region will further be raised by $2.24 \mathrm{~g} / \mathrm{l}$ by 2050. There is also a continuous threat of algal blooms caused by global warming (Laffoley and Baxter, 2016). The harmful algal blooms are only considered as an extreme threat to the water quality but it also a threat for seawater reverse osmosis desalination (Michalak, 2016; Villacorte et al., 2015). Similarly, there is no balance between the groundwater extraction and replacement rate. For instance, in Dubai, groundwater extraction is 12 times more than the replacement rate. Although the government aims to reduce the extraction rate, the target set for this is still non-sustainable.

The current score of Goal 7 (Affordable and Clean Energy) is 84.9, wherein challenges still remain; the trend reflects that the Goal is on track to achieve by 2030 . At the same time, the construction of a coal plant in UAE is in progress which is expected to be completed by 2023. It is expected that the plant will produce a 2,400 $\mathrm{MW}$ of electricity using ultra-supercritical technology with a $14 \%$ lower $\mathrm{SO}_{2}$ emission than the subcritical plant. In other words, electricity generation will increase but the production will not be clean and the overall GHG emissions will increase which will affect the achievement of other Goals. Similarly, the planned solar capacity is more than the capacity of the coal plant, which could also be cheaper (if subsidies), than the subsidies gas (IRENA, 2019). Some of the targets related to the clean energy set by the government organization, for instance, $3 \mathrm{GW}$ generations from hydro by 2050, appear not to be feasible considering the water and the topographic conditions of the country. Overall, the country is going in a very wrong direction considering an environment, financial and economic point of view.

Similarly, based on the current score of Goal 8 (Decent Work and Economic Growth, score = 86.4), it is also considered as achieved and the trend of the goal is on track to achieve by 2030. The economy is, however, highly reliant on oil and gas export. For instance, in 2011 the oil exports accounted for $77 \%$ of the UAE's state budget. The current official statistics indicate that the contribution of oil and gas to the GDP is still 30\%, while in the Vision 2021 the top KPI is the Non-oil real GDP growth. There are also challenges ahead with Goal 9 (Industry, Innovation, and Infrastructure). Dubai metro, the first 3D office in Dubai, and other infrastructure projects are some of the initiatives which have a good reflection but on the other side, such projects create a large quantity of waste. For instance, the construction and demolition waste accounts for $70 \%$ of the total waste in the UAE. Similarly, the study conducted by Swain (2018) reported that 
Dubai alone produces nearly 5,000 tonnes of construction and demolition waste every day. It is important that along with infrastructure development, necessary actions are required to reduce and recycle the waste generated from such development projects (Swain, 2018). The ranking based on the Logistics Performance Index (LPI) of UAE is improved from 13 (2016) to 11 (2018) (WB, 2018). The LPI was also considered by Sachs et al. (2019) as one of the indicators for measuring the Goal 8 performance. Overall, there are some good ideas in play for the economy but there is not enough diversity and thus the future Goal looks grim.

Goal 11 (Sustainable Cities and Communities) is among those goals where significant challenges are ahead. As discussed in the introduction section the PM2.5 value for UAE is quite high as compared with some other countries. The World Bank data further reveals that the PM2.5 in the United Arab Emirates is continuously increasing which was 39.82 micrograms per cubic meter in 1990 and have reached to 40.92 micrograms per cubic meter in 2017 (WB, 2017). There is a need for coordinated actions to gear up the work on sustainable cities. The traditional method of procurement which only considered the financial matrix required to incorporate the sustainability indicators. The promises in terms of reduction in emissions made for Dubai Expo 2020 required to be maintained to reflect the commitment towards sustainable development. To achieve Goal 11, different organizations need to develop and maintain a close relationship so that the efforts of one organization don't derail the actions of other organizations. In Emirates, the siloed approach of different agencies particularly undermines Goal 11.

The key Goals where the UAE has major challenges are Goal 12 (Responsible Consumption and Production) and goal 13 (Climate Change). As discussed in the introduction section, the electricity consumption per capita in the UAE is quite high and most of the electricity production is based on oil, gas, and coal, which further produces a high quantity of emissions. Apart from a high municipal solid waste generation per capita (1.7 kg per day), construction and demolition waste are estimated at 5,000 tonnes per day (Zafar, 2018; Swain, 2018). Similarly, the Central Bank's latest statistics show that the UAE's petroleum exports (hydrocarbons) grew by 13.9 percent to US\$ 66.2 billion in 2019 compared with US\$ 58.1 billion in 2017 (ITA, 2019). This high level of consumption of resources increases the ecological footprint and thus the UAE required at least 4.5 planets to sustain such consumptions (GFN, 2015). The main problem related to this Goal (Responsible Consumption and Production) is the consumption of natural resources, and this is something because of the consuming culture in Emirates. Until and unless this culture is changed, reducing waste or recycling would not add any value. There are some good actions such as the promotion of electric vehicles in relation to climate action (Goal 13). Several statistics indicate that the electric vehicles market in the UAE is expected to grow at a compound annual growth rate of 32.1\% during 2019-2025 (Research and Markets, 2019).

The protection of mangroves and seagrass is also important in relation to climate change as they act as green lungs for most of the main cities in the UAE. Currently, these mangroves and seagrass are exposed to several threads including the expansion of cities, leak of freshwater, and 
pollutions. Climate actions will, therefore, required a significant reduction in consumptions and promoting agriculture and plantation.

Similarly, the performance of Goal 14 (life below water) is increasing at less than 50\% of the required rate. The performance related to the fish stocks is particularly, decreasing, despite the fact the government has initiated some regulations to regulate professional fishing (MD:471, 2016). A report published by the Environment Agency of Abu Dhabi in 2017 indicates that in the UAE the number of fishing vessels has increased from 1,065 in 1976 to 5,985 in 2015 (Environment Agency, 2017). It is important to note that the most landed demersal species, Hamour, Shaari, and Farsh, are being over-exploited by an estimated five times the sustainable limit, while the pelagic kingfish are being over-exploited by up to three times its sustainable limit the report further indicates that in 2015, a more than $90 \%$ decline in the adult (reproductive) stock size in Abu Dhabi Emirate had been estimated for the three key demersal indicator species. A study conducted by Jabado et al., (2015) on shark fishery in UAE suggests that sharks are likely to be overexploited and that management measures will need to take into account the precautionary principle. They noted that there is an urgent need to formulate long-term and effective conservation and management plans to prevent further declines in a number of species.

The score of different performance indicators related to goal 15 (life on land) such as the "red list index of species survival" is also decreasing. The encroachment to sea area needs to be stopped so that the life below the water can be protected and the goal can be achieved. Similarly, Howarth et al., (2019) in their study on the challenges faced by land set aside as protected areas noted that the intent to protect is interpreted in a variety of conflicting ways by stakeholders, specifically those that intend to pursue wealth accumulation through projects within the protected areas that do not enhance the conservation aspects, but also by a variety of interpretations of the intent of the protective areas protective status. For instance, the project started in the name of the "Marmoom Desert Conservation Reserve" also includes the cultural, sports and sports events, lakes, and plant nursery (The national, 2018). Similarly, the coal-fired power plant and desalination plant at Jebel Ali Wildlife Sanctuary look odd particularly when conservation is a priority. The justification of such a power plant becomes difficult if energy pricing, energy efficiency, and realistic population forecasts are considered. Clearly, such activities required some infrastructures and thus compromise the status of the protected areas.

Overall, the ranking of each goal based on their mean score of the United Arab Emirates established by (Sachs et al., 2018) is given in figure 8. The discussion presented in this paper, however, shows a different picture which is further summarized in table 1. Although Goal 10 (Reduced Inequalities) is not included in the figure as this goal is not scored in the 2018 report due to the non-availability of information, inequalities in the wages are, however, reported in a number of studies. For instance, the book authored by Daleure on the UAE labor market reveals a great difference in the salaries of the workers of different nationalities. The monthly earning of North Americans in the UAE are six times more than the Asian workers. In fact, the Emiratis' salaries are reported to be lower than the North Americans working in the UAE (Daleure, 2017). 
There is also a big difference in the working hours of workers from different nationalities. The construction workers are particularly getting the lowest salary when compared with the other 14 different categories of professions (FCSA, 2009). Apart from the difference in salaries, the construction workers in the whole GCC region have poor occupational safety and health facilities (Umar et al., 2018; Umar and Wamuziri, 2017; Umar, 2017-c).

In terms of Goal 16 (Peace, Justice, and Strong Institutions), the UAE is ranked $53^{\text {rd }}$ among 163 countries for peace by the Global Peace Index (GPI, 2019). Similarly, the World Justice Project Index ranked UAE at $32^{\text {nd }}$ out of 126 countries for the rule of law (WJPI, 2019). In terms of the press freedom index, the UAE ranking is not quite good, standing at $133^{\text {rd }}$ out of 180 countries (Reporters without Borders, 2019).

The global score for Goal 17 (Partnership for the Goals) is satisfactory; however, there is a strong need for coordination among organizations responsible for different goals so that the efforts of one organization for the achievement of a specific goal don't derail the other goals. Similarly, strong ties need to be established with the countries that have demonstrated good progress towards different goals so that to get advantages from their experience.

The rating and trend of these goals are further summarized in table 1 .

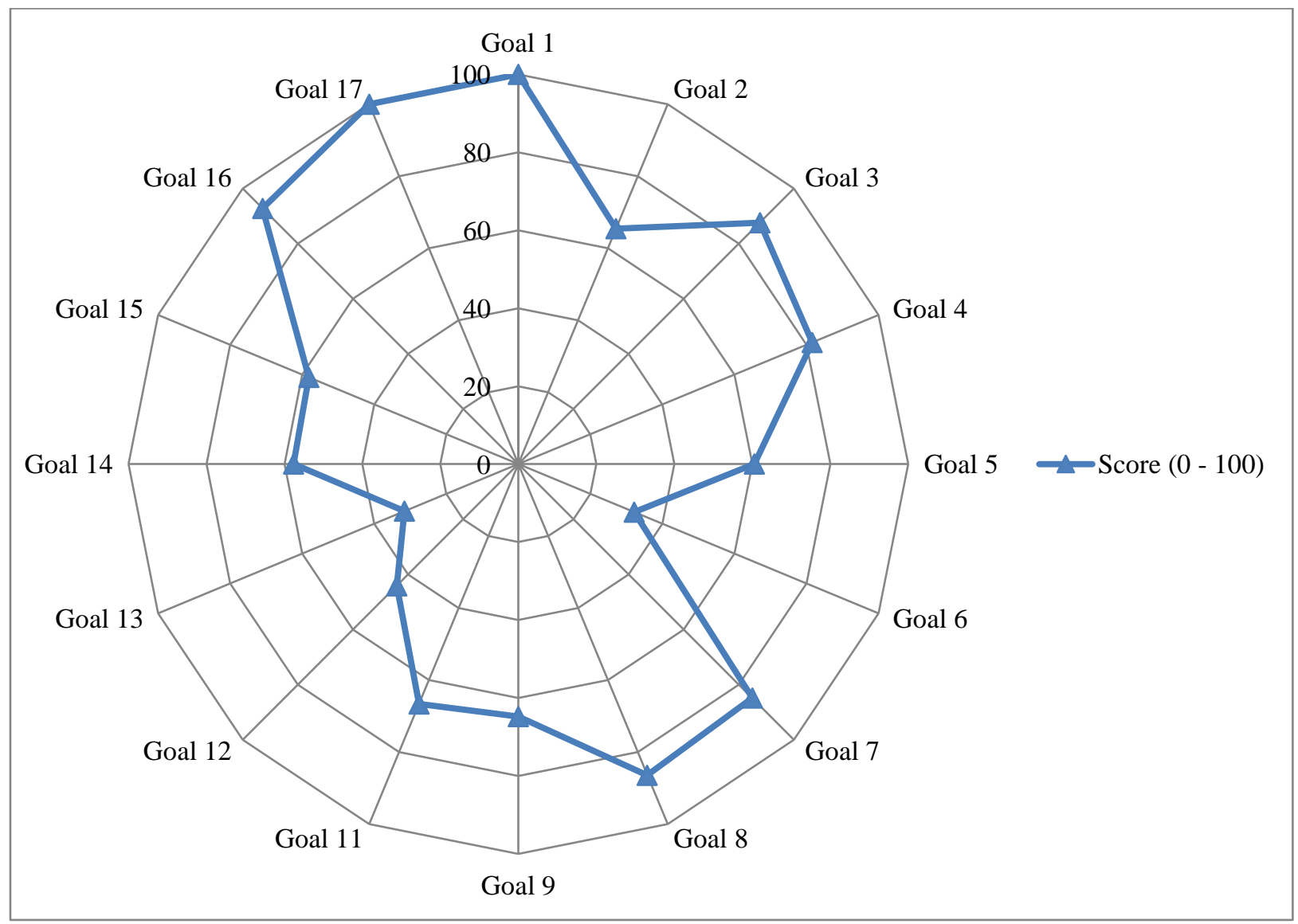


Figure 8: United Arab Emirates Scores of Different UN SDGs (Sachs et al., 2018)

\begin{tabular}{|c|c|c|c|}
\hline Goals & $\begin{array}{c}\text { Score }(0-100) \\
\text { based on } \\
\text { Sachs et al. } \\
(2018) \\
\end{array}$ & Rating & Trend \\
\hline Goal 1: No Poverty & 100 & Not achieved, challenges remain & Getting riskier \\
\hline Goal 2: Zero Hunger & 65.4 & Major challenges remain & Getting riskier \\
\hline $\begin{array}{l}\text { Goal 3: Good Health and } \\
\text { Well Being }\end{array}$ & 87.6 & Significant challenges remain & $\begin{array}{l}\text { Score moderately increasing, } \\
\text { insufficient to attain the goal }\end{array}$ \\
\hline Goal 4: Quality Education & 81.6 & Significant challenges remain & $\begin{array}{l}\text { Score moderately increasing, } \\
\text { insufficient to attain the goal }\end{array}$ \\
\hline Goal 5: Gender Equality & 60.5 & Significant challenges remain & $\begin{array}{l}\text { Score stagnating or increasing at } \\
\text { less than } 50 \% \text { of the required rate }\end{array}$ \\
\hline $\begin{array}{l}\text { Goal 6: Clean Water and } \\
\text { Sanitation }\end{array}$ & 32.2 & Major challenges remain & Getting riskier \\
\hline $\begin{array}{l}\text { Goal 7: Affordable and } \\
\text { Clean Energy }\end{array}$ & 84.9 & Challenges remain & Getting riskier \\
\hline $\begin{array}{l}\text { Goal 8: Decent Work and } \\
\text { Economic Growth }\end{array}$ & 86.4 & Not achieved, challenges remain & Not on track to achieve by 2030 \\
\hline $\begin{array}{l}\text { Goal 9: Industry, Innovation, } \\
\text { and Infrastructure }\end{array}$ & 64.8 & Significant challenges remain & Not on track to achieve by 2030 \\
\hline $\begin{array}{l}\text { Goal 10: Reduced } \\
\text { Inequalities }\end{array}$ & N/A & Not achieved, challenges remain & Not on track to achieve by 2030 \\
\hline $\begin{array}{l}\text { Goal 11: Sustainable Cities } \\
\text { and Communities }\end{array}$ & 66.6 & Significant challenges remain & Trend information unavailable \\
\hline $\begin{array}{l}\text { Goal 12: Responsible } \\
\text { Consumption and } \\
\text { Production }\end{array}$ & 44.1 & Major challenges remain & Trend information unavailable \\
\hline Goal 13: Climate Action & 31.6 & Major challenges remain & $\begin{array}{l}\text { Score decreasing. Not on track to } \\
\text { achieve by } 2030\end{array}$ \\
\hline $\begin{array}{l}\text { Goal 14: Life Below the } \\
\text { water }\end{array}$ & 57.7 & Significant challenges remain & Not on track to achieve by 2030 \\
\hline Goal 15: Life on Land & 58.2 & Significant challenges remain & Not on track to achieve by 2030 \\
\hline $\begin{array}{l}\text { Goal 16: Peace, Justice and } \\
\text { Strong Institutions }\end{array}$ & 92.8 & Challenges remain & Maintaining SDG achievement \\
\hline $\begin{array}{l}\text { Goal 17: Partnership for the } \\
\text { Goals }\end{array}$ & 100 & SDG achieved & Trend information unavailable \\
\hline
\end{tabular}

Table 1: United Arab Emirates Goals' Rating and Trend 
The next section provides an insight into the Emirates government's commitment towards the achievement of UN SDGs, especially those which are rated with major challenges.

\subsection{Emirates' Commitment Towards UN SDGs:}

A report submitted to the UN on Emirates 2030 agenda for sustainable development shows that the country has established a National Committee in 2017, known as "UAE's National Committee on SDGs". This committee has members from all the relevant ministries and government organizations (NCSDG, 2017). Each ministry or organization is responsible for specific UN SDGs which directly or indirectly fall under that ministry or organization jurisdiction (table 2). For instance, Goal 6 (Clean Water and Sanitation) fall under the responsibility of the Ministry of Energy and Industry. Similarly, the Ministry of Climate Change \& Environment has a major role in Goals 12 (Responsible Consumption and Production) and Goal 13 (Climate Change). As mentioned in table 1, Emirates has major challenges in all these 3 Goals.

\begin{tabular}{|c|c|}
\hline $\begin{array}{l}\text { National Committee Members } \\
\text { (Organizations) }\end{array}$ & $\begin{array}{l}\text { Roles / Responsibilities of the } \\
\text { Organizations }\end{array}$ \\
\hline $\begin{array}{l}\text { Federal Competitiveness \& Statistics } \\
\text { Authority }\end{array}$ & $\begin{array}{l}\text { - Vice-Chair and secretariat of the National } \\
\text { Committee }\end{array}$ \\
\hline Ministry of Cabinet and Future & $\begin{array}{l}\text { - The cross-cutting role for state sector } \\
\text { strategy and performance }\end{array}$ \\
\hline Ministry of Community Development & - Goals 1,10 \\
\hline $\begin{array}{l}\text { Ministry of Climate Change and } \\
\text { Environment }\end{array}$ & - Goals $2,12,13,14,15$ \\
\hline Ministry of Health \& Prevention & - Goal 3 \\
\hline Ministry of Education & - Goal 4 \\
\hline Gender Balance Council & $\begin{array}{l}\text { - Goal } 5 \\
\text { - Cross-cutting role to ensure policy } \\
\text { coherence on gender issues }\end{array}$ \\
\hline Ministry of Energy \& Industry & - Goals 6, 7 \\
\hline $\begin{array}{l}\text { Ministry of Human Resources \& } \\
\text { Emiratization }\end{array}$ & - Goal 8 \\
\hline Ministry of Economy & - Goal 9 \\
\hline Ministry of Infrastructure Development & - Goal 11 \\
\hline Ministry of Interior & - Goal 16 \\
\hline $\begin{array}{l}\text { Ministry of Foreign Affairs \& International } \\
\text { Cooperation }\end{array}$ & $\begin{array}{l}\text { - Goal } 17 \\
\text { - Cross cutting role on international } \\
\text { engagement }\end{array}$ \\
\hline Central Bank & $\begin{array}{l}\text { - Cross-cutting role liaising with the } \\
\text { Ministry of Finance }\end{array}$ \\
\hline General Youth \& Sports Authority & $\begin{array}{l}\text { - Cross-cutting role to ensure policy } \\
\text { coherence for youth welfare }\end{array}$ \\
\hline
\end{tabular}

Table 2: Roles and Responsibilities of Different Organizations to Achieve UN SDGs 
Although, according to the 2016 ARCADIS Sustainable Cities Index, Dubai (rank = 52) and Abu Dhabi (rank = 58) were the only cities from GCC, ranked among top 100 sustainable cities and were the top-ranked Middle Eastern cities in the provision of high standards of water and sanitation networks (ARCADIS, 2016). The 2018 raking, however, shows that none of the Emirates cities are included in the top 100 rankings of the ARCADIS Sustainable Cities Index (ARCADIS, 2018). This clearly, reflects that Emirates was not able to maintain its city's performance. Apparently, the Emirati government has realized this therefore recently, the government has launched the Water Security Strategy, 2036 in 2017 (WSS, 2017). The overall objectives of the strategy are to increase water productivity and reduce water scarcity. The Water Security Strategy, 2036 focuses on reducing the total demand for water, increasing the reuse of treated wastewater and increasing the national water storage capacity. The Water Security Strategy, 2036 has also adopted a number of National Key Performance Indicators (KPIs) that measure Available storage, Municipal consumption, Sewage water collection rate, Treated Sewage Effluent reuse rate, Reduction in groundwater demand, Unaccounted for water, Water productivity Index and Water Scarcity Index. The Water Security Strategy has also set a target to increase the treated sewage effluent usage up to $95 \%$ by 2036 which was $64 \%$ in 2016 . These KPIs are expected to significantly improve the performance of the country's water sector. Similarly, Dubai Electricity and Water Authority (DEWA) which is responsible for electricity and water in Dubai, has joined hands together with national organizations to achieve the concerned UN SDGs. DEWA is committed to implementing an integrated strategy to raise awareness about conservation and the reduction of electricity and water use. The 2018 sustainability report of DEWA shows that from 2006 to 2018, a total of 50.5 million tonnes of $\mathrm{CO}_{2}$ emissions have been reduced by the efforts of DEWA. The report further indicates that water and electricity line losses in Dubai were only $6.5 \%$ and $3.3 \%$ respectively. The report reflects the commitment of DEWA to $25 \%$ renewables generation capacity by 2030 , and $75 \%$ by 2050 (DEWA, 2018).

The concept of sustainable consumption and production is underlined by the United Arab Emirates' Green Growth Strategy also known as the Green Economy initiative which was launched under the slogan of "A green economy for sustainable development" and the "UAE Green Agenda 2015-2030” (TGE, 2012; UAEGA, 2015). The Green Economy initiative includes six major fields covering a wide range of legislation, policies, programs, and projects which are:

1. Green Energy aims to promote the production and use of renewable energy.

2. Government Policies aimed to encourage investments in the green economy and to facilitate the production, import, export, and re-export of green products and technologies.

3. Developing urban planning policies that preserve the environment and to raise the efficiency of housing and buildings environmentally. 
4. Developing new means for dealing with the effects of climate change, promote organic agriculture, maintain biodiversity and protect the ecological balance.

5. Rationalizing the use of water resources, electricity, and natural resources and recycle waste.

6. Development and promotion of green technology.

There have been several partnerships between Government and private industrial sectors which reflect that there has been some progress towards achieving Goal 13; Responsible Consumption and Production in the United Arab Emirates. The partnership between Emirates Global Aluminum and cement factories across the United Arab Emirates has successfully demonstrated the utilization of aluminum waste as an energy source in cement production (Zawaya, 2017). Only this partnership has resulted in a reduction of emission by $10 \%$ in each tonne of cement produced. As mentioned in figure 2 and figure 3, resource consumption and waste generation not only in the United Arab Emirates but in the whole GCC region are comparatively high. This has negatively affected the environment as shown in figure 9. Although, the amount of particulate matter in the United Arab Emirates is high but comparatively lower than other GCC countries. The amount of particulate matter in Iran, a neighboring country of the United Arab Emirates, is $35.10 \mathrm{ug} / \mathrm{m}^{3}$, which is lower than all countries in the GCC region. The World Bank's Little Green Book data reveals that air quality is getting worse in the Emirates. The PM2.5 value in Emirates which was $39.82 \mathrm{ug} / \mathrm{m}^{3}$ in 1990 has reached $40.91 \mathrm{ug} / \mathrm{m}^{3}$ in $\left.2017 \mathrm{WBLGB}, 2017\right)$. The main reason for this is that most of the electricity (almost 100\%) in GCC countries is produced from fossil fuels which results in a huge amount of emission. Different estimates show that 0.0016 barrels of oil are required to produce one $\mathrm{kWh}$ of electricity and one barrel of oil produces 0.43 tonnes $\mathrm{CO}_{2}$ (EIA, 2017; EPA, 2018). In other countries for instance, in Sweden, the PM2.5 value has reduced from $7.94 \mathrm{ug} / \mathrm{m}^{3}$ (1990) to $6.18 \mathrm{ug} / \mathrm{m}^{3}$ (2017), which reflects their serious commitment towards UN SDGs. 


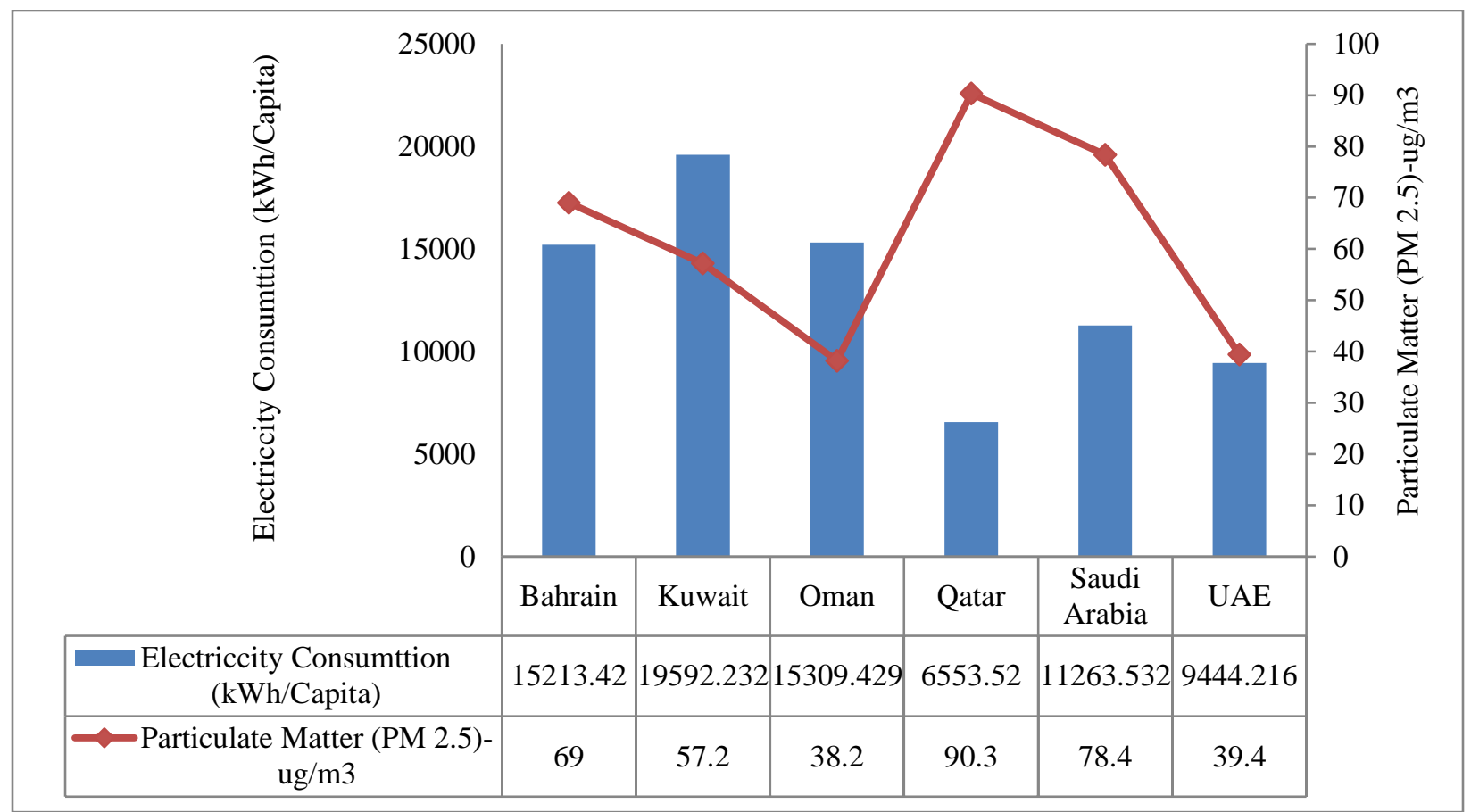

Figure 9: Electricity Consumption and Particulate Matter in GCC Countries (WB, 2014-a, WHO, 2016)

The United Arab Emirates, however, have initiated some project related to the generation of energy renewable sources such as nuclear, solar, wind and waste. All these projects are aligned with the National Energy Strategy 2050 which was launch in January 2017. The strategy aims to achieve $50 \%$ clean energy capacity by 2050 as well as a $40 \%$ reduction in electricity and water consumption (UAEES, 2017). The strategy further aims to increase the contribution of clean energy in the total energy mix from $25 \%$ to $50 \%$ by 2050 and reduce the carbon footprint of power generation by $70 \%$, which will result in a saving of US\$ 190.57 billion (AED 700 billion) by 2050. The strategy also seeks to increase the consumption efficiency of individuals and corporates by $40 \%$. The relevant agencies, however, don't mention how these significant goals will be achieved. Some of the strategies related to hydropower as discussed in section 3.1, don't consider the realistic waster and topographic conditions of Dubai. Thus the achievement of such goals would not be possible and the strategy would ultimately fail. The Government is committed to invest US\$ 163.35 billion (AED 600 billion) by 2050 in all renewable energy projects that ensure sustainable growth for the country's economy. The Emirates' commitment towards energy is somehow reflected from the World Energy Council database, wherein Emirates has improved its raking from 43 in 2016, to 36 in 2018 (WEC, 2018). In the same database, the environmental sustainability ranking is however reduced from 113 to 116 in the same period. The Government, therefore, needs to keep a close eye on the overall progress and to ensure that the progress is in the right direction. 


\subsection{Results and Discussion of Semi-Structured Interview:}

Respondents were asked to relate the UN SDGs to their current job assignment and to shed light on their current role and its importance in the achievement of these goals. The majority of the interviewees (18 participants; 90\%) answered positively and explained how these goals are linked with their work and how their job is playing a role to achieve them. These respondents provided examples and justifications on the association between their job and the UN SDGs and how these respondents are playing their role in achieving these goals in their work. Two of the respondents were somehow not able to establish a relationship between their current jobs and the UN SDGs. When the respondents were asked do they have observed any directive from the government organizations that asked for compliance with the UN SDGs, the response of all the participants was negative. Six out of 10 respondents, however, clarified that engineering sustainability remains as one of the top priorities of their work based on their organization's policy, design requirement, and client requirement that includes government entities projects. Such inclusions of the engineering sustainability in the projects in the UAE reflect government and organizations' commitment towards sustainability.

In response to the question related to the achievement of the UN SDGs by 2030, the participants provided detailed and positive comments on the goal 6,7, 8, 9, 11, 12, 13 and seventeen. They also showed some concerns with most of the goals. Respondents noted that goal 6 , which is related to clean water and sanitation, can be easily achieved by 2030 as this has enough government attention. The problem with water would arise later after 2030 when the population will increase as the region fall under the water-stressed area. The use of potable water has some merits, but since such water came from desalination, there could be problems with this approach in the future. The government, therefore, needs to keep a close eye on this not only to comply with the UN but also to tackle the great challenge associated with the future water requirement. The World Resources Institute also indicated that the UAE is among the 17 countries that fall under the category of extremely high water stress (Hofste et al., 2019). With regard to goal 7 (affordable and clean energy), all the respondents agreed that the price of energy in the UAE is comparatively low and everyone has access to electricity. The respondents, however, questions on the commitment towards renewable energy and stated that such commitment now should come out of the documents to the ground. The respondents also showed a greater concern with goals 12 (responsible consumption and production) and 13 (climate action). There was an agreement among the respondents which reflects that if the government does not take serious action related to these goals, they may not be achieved by 2030 .

Different respondents rated the overall commitment which includes the commitment from the government, private sectors and the individuals towards UN SDGs at different rates. The overall rating considering all the participant's responses stand at 2.8 on a scale of 1 to $5(1=$ no commitment at all, $5=$ strong commitment). This clearly, reflects that even if there is a commitment to achieve these goals, it is not recognized very well at least from the respondents participated in this study. The government and other sectors, therefore, need to demonstrate their 
commitment and should publicize such commitment so that it can be easily recognized by society.

Most of the respondents agreed that there is a wide range of opportunities that exist for the UAE to achieve UN SDGs. The majority of these opportunities noted by the respondents were related to the business and displaying the countries among the nations which are highly civilized and mature. Respondents 3 and 5 precisely mentioned investment of the renewable energy sector which will not only help the country to achieve the UN SDGs, reduce the emissions, but also make the UAE as a hub for renewable energy technologies. Similarly, respondents 1 and 7 noted that currently, different industrial sectors are producing a huge amount of waste in different forms. Recycling and reuse of such waste will not only reduce the burden of waste on the environment but will also reduce the cost of manufacturing and construction when the waste will be used for different purposes.

There was a consensus among the respondents that the main challenge towards achieving the UN SDGs is the reflection of the commitments of the government. Participants 9 and 10 noted that currently, such commitment even if exist is not displayed properly. Respondents 1 and 3 mentioned that although the top government institution is very clear on the importance and achievement of UN SDGs, there are problems among the lower organizations ranging from coordination to implementation. They noted that there are cultural and managerial issues at lower organizations and such issues detracting the top government commitment to achieving any goal. Participant 8 emphasized on the erection of a national-level committee which is fully empowered to lead the agenda of UN SDGs. Coordination among the government entities which have a major role in different goals was also identified by remaining respondents as a major challenge towards achieving these goals.

Different respondents provided different views on what the UAE has to do to achieve the UN SDGs in due course of time. Respondents 1 stressed on the prioritizing the key goals where the progress is very low and then develop an effective strategy to achieve it. Such a strategy should jump from the paper and the progress should appear on the ground. Respondents 2, 3 and 4 advised that it would be better to learn from the experience of other countries that have achieved or shown good progress on UN SDGs. Respondents 6 and 8 noted that these goals will never be achieved without a strong commitment and coordination among different government entities. The government needs to establish a high-level committee that is empowered to lead the cause. Such a committee needs to be fully empowered and can direct all the concerned government institutions. What needs to be done and by whom should be prepared and distributed among concerned organizations. There are possibilities that one goal will have several actions that need to be taken by different organizations, such actions, therefore, require high levels of coordination. Similarly, respondents 5 and 7 also emphasized on a national-level plan that highlights what should be done and by whom to achieve these goals.

The next section provides the overall conclusion of the research presented in this paper. 


\section{Conclusion:}

The UN SDGs agreed by all nations on the earth under the umbrella of the UN is a great achievement of the current decade. These goals are important to improve the quality of life on earth in a sustainable way; therefore, efforts are underway to achieve these goals. Some countries are leading these efforts and are on the path to successfully achieve these goals by 2030; however, some countries are still in the preparatory stage. This article discussed the progress and commitment of the United Arab Emirates towards these goals. GCC countries are normally regarded as the main consumer of the earth's resources, and somehow it is reflected from the waste and $\mathrm{CO}_{2}$ generation in the region. The results and analysis presented in this paper reveal that the Emirate's progress towards achieving the UN SDGs is slow and none of the Goals are on track to be achieved by 2030. The latest progress reports complied by Sachs et al. (2019) on these Goals shows that Emirates is leading the GCC region and ranked first among the GCC countries. Advanced countries such as the United States and the United Kingdom still have not achieved any of these goals. Sweden which raked as first in 2018, has only achieved two Goals so far. The global index score used by Sach et al. (2018) to rank the countries based on their progress towards UN SDGs report the Sweden score as 85 which is quite more than the score of Emirates (=69.7). Similarly, in 2019, Demark was ranked first with a total global index score of 85.2 while Sweden stood at the second position. Emirates' was able to score the $65^{\text {th }}$ position in 2019 ranking. While the assessment of each sustainable development goal required detailed information related to a particular goal, which is not in the scope of this paper, however, to provide a snapshot of the situation that why Denmark or Sweden is ahead of the Emirates in terms of global index score. In this regard, it needs to be noted that although Sweden had achieved two goals in 2018, however, in 2019, they have now achieved three goals and further seen goals are on track to be achieved by 2030. Similarly, as of 2019, Demark has also achieved three goals and six others are on the right track to be achieved by 2030. The situation over Emirates' progress is, however, not as of Sweden or Denmark. Emirates' apart from not achieving most of the goals, the majority of these goals are not on track to be achieved by 2030. Apart from this, relevant information for the effective assessment of many goals in Emirates is currently not available. The progress of Emirates on Goal 13 (Climate Action) is, however, reducing and there as major challenges which the country is still facing. The most important challenge in this regard is the $\mathrm{CO}_{2}$ emissions from energy as most of the energy used in the country is produced from fossil fuels. In this regard, different clean energy strategies developed by the Government are some good steps towards climate action, but at the same time, these strategies are undermined by the construction of the coal plant. Similarly, some of the goals as noted in table 1, are getting more riskier. Most of the indicators related to Goal 14 (Life Below Water) are getting worse. There are regulations that exist to protect demersal species, however, these regulations are not effectively implemented. Long-term and effective conservation and management plans to prevent further declines in a number of species are therefore important to achieve this Goal. The conservation and sustainably use biodiversity and ecosystems is therefore important to achieve both Goals 14 and 15. Some of the initiatives started by the Government, however, reflect the 
commitment to achieve all the remaining Goals by 2030. In fact, the Emirates Government has adopted the UN SDGs as National Sustainable Development and a high level of the council is monitoring the progress of each Goal assign to different Ministries and Government Organizations. In relation to Climate Action, the 'UAE Green Agenda 2015-2030' launched in 2015 and 'National Energy Strategy 2050', launched in January 2017, target to achieve 50\% clean energy by 2050 and to reduce electricity and water consumption by $40 \%$. The Government aims to invest a total of US \$ 163.35 billion to achieve the target of 'UAE Green Agenda' and 'National Energy Strategy 2050'. The sub-national agency, however, should not aim for a reduction in business, as this can increase the overall greenhouse gas emissions. To successfully achieve UN SDGs, the government needs to ensure that all responsible organizations work closely with a high level of coordination. The plans and progress of each organization need to be closely monitored so that to ensure that they are in the right direction and don't create an obstacle for another organization working on different goals. Although the results of the semistructured interview held with a number of respondents reflect that the Emirates would be able to achieve the UN SDGs by 2030, however, they also identify some challenges which need the attention of the government. The participants particularly stressed on the need for very close coordination among the national agencies responsible for different goals. The Emirates Government needs to keep a close eye on the progress of all the Goals, particularly those which have significant and major challenges ahead. At the same time, the Government needs to share their experience with other countries, particularly in the GCC region so that the overall progress towards UN SDGs could be excelled.

\section{Acknowledgment:}

The author (s) acknowledges the comments of the Assessor (Editor) and the two anonymous reviewers in the development of the final version of this paper.

\section{References:}

ARCADIS (2016). Sustainable Cities Index 2016. The Sustainable Cities Index explores the three demands of People, Planet and Profit to develop an indicative ranking of 100 of the world's leading cities. ARCADIS, Amsterdam, Netherlands. See: https://www.arcadis.com/en/global/our-perspectives/sustainable-cities-index-2016/comparingcities $/ \mathrm{tf}=\mathrm{tab}-$ overall $\& \mathrm{sf}=\mathrm{all} \& \mathrm{r}=\mathrm{all} \& \mathrm{c}=\mathrm{all}($ accessed $28 / 04 / 2019)$.

ARCADIS (2018). Citizen Centric Cities. The Sustainable Cities Index 2018. ARCADIS, Amsterdam, Netherlands. See: https://www.arcadis.com/en/global/ourperspectives/sustainable-cities-index-2018/citizen-centric-cities/ (accessed 28/04/2019).

Bashitialshaaer, R.A., Persson, K.M. and Aljaradin, M., 2011. Estimated future salinity in the Arabian Gulf, the Mediterranean Sea and the Red Sea consequences of brine discharge from desalination. International Journal of Academic Research, 3(1). 
BBB (Bharat Book Bureau), 2015. Cement market in the UE, 2015-2019. Bharat Book Bureau, Mumbai, India. See: https://www.prnewswire.com/news-releases/cement-market-in-the-uae2015-2019-300113860.html (accessed 25/09/2019).

Brundtland Commission, 1987. Our Common Future. Oxford University Press: Oxford, London, United Kingdom. See:

https://sswm.info/sites/default/files/reference_attachments/UN\%20WCED\%201987\%20Brundtla nd\%20Report.pdf (accessed 23/04/2019).

Bryman, Alan. Social research methods. $5^{\text {th }}$ Edition. Oxford university press, 2016. Oxford, United Kingdom.

CDIAC (Carbon Dioxide Information Analysis Center), 2017. $\mathrm{CO}_{2}$ emissions (metric tons per capita). Carbon Dioxide Information Analysis Center, US Department of Energy, James V. Forrestal Building, Washington, D.C., United States. See: https://cdiac.ess-dive.lbl.gov/ (accessed 29/09/2019).

Cohen, A.J., Brauer, M., Burnett, R., Anderson, H.R., Frostad, J., Estep, K., Balakrishnan, K., Brunekreef, B., Dandona, L., Dandona, R. and Feigin, V., 2017. Estimates and 25-year trends of the global burden of disease attributable to ambient air pollution: an analysis of data from the Global Burden of Diseases Study 2015. The Lancet, 389(10082), pp.19071918. https://doi.org/10.1016/s0140-6736(17)30505-6.

Cooper, D.R., Schindler, P.S. and Sun, J., 2006. Business research methods (Vol. 9). McGrawHill Irwin. New York, United States.

Cruickshank, H.J. and Fenner, R.A., 2007. The evolving role of engineers: towards sustainable development of the built environment. Journal of International Development: The Journal of the Development Studies Association, 19(1), pp.111-121. https://doi.org/10.1002/jid.1352.

Daleure, G. (2017). Emiratization in the UAE Labor Market. Springer Nature. Singapore. http://dx.doi.org/10.1007/978-981-10-2765-9.

DEWA (Dubai Electricity and Water Authority), 2018. DEWA Sustainability Report 2018. Dubai Electricity and Water Authority, Dubai, United Arab Emirates. See: https://www.dewa.gov.ae/en/customer/sustainability/conserve-now/sustainability-reports (accessed 26/09/2019).

EIA (Energy Information Administration), 2017. How much coal, natural gas, or petroleum is used to generate a kilowatt-hour of electricity. US, Energy Information Administration. Washington, USA. See: https://www.eia.gov/tools/faqs/faq.php?id=667\&t=6 (accessed 05/10/2017).

Environment Agency, 2017. Abu Dhabi State Of Environment Report, 2017. Environment Agency, Abu Dhabi, United Arab Emirates. See: https://www.soe.ae/wpcontent/uploads/2017/11/Fisheries English.pdf (accessed 25/11/2019).

EPA (Environmental Protection Agency), 2017. Air Quality - Cities and Counties, Environmental Protection Agency, Washington, D.C., United States. See: https://www.epa.gov/air-trends/air-quality-cities-and-counties (accessed 25/03/2019). 
EPA (Environmental Protection Agency), 2018. Greenhouse Gases Equivalencies Calculator Calculations and References. Washington, USA. See:

https://www.epa.gov/energy/greenhouse-gases-equivalencies-calculator-calculations-andreferences (accessed 04/10/2018).

FCSA (The Federal Competitiveness and Statistics Authority), 2009. Employment, wages, and hours worked survey 2008. See: www.fcsa.gov.ae (accessed 24/11/2019).

GFN (Global Footprint Network), 2015. United Arab Emirates - Case Study. Global Footprint Network, Oakland, California, United States. See: https://www.footprintnetwork.org/2015/11/18/united-arab-emirates/ (accessed 24/11/2019).

GFN (Global Footprint Network), 2019. Open Data-United Arab Emirates. Global Footprint Network , Oakland, California, United States. See: http://data.footprintnetwork.org/? ga=2.3604272.1090939346.15739909692026566792.1573990969\#/ (accessed 17/11/2019).

GFSI (Global Food Security Index), 2018. The Global Food Security Index, The Economist Intelligence Unit Limited, London, United Kingdom. See: https://foodsecurityindex.eiu.com/Downloads (accessed 17/11/2019).

GPI (Global Pleace Index), 2019. Measuring Peace In A Complex World. Global Pleace Index. Institute for Economics \& Peace, Sydney, Australia. See: https://reliefweb.int/sites/reliefweb.int/files/resources/GPI-2019-web003.pdf (accessed 25/11/2019).

Head, P., 2009, May. Entering an ecological age: the engineer's role. Proceedings of the Institution of Civil Engineers-Civil Engineering (Vol. 162, No. 2, pp. 70-75). Thomas Telford Ltd. https://doi.org/10.1680/cien.2009.162.2.70.

Hofste, RW., Reig, P., and Schleifer, L., 2019. 17 Countries, Home to One-Quarter of the World's Population, Face Extremely High Water Stress. World Resources Institute, Washington, D.C., United States. See: https://www.wri.org/blog/2019/08/17-countries-homeone-quarter-world-population-face-extremely-high-water-stress. (accessed 26/09/2019).

Honnur Vali, M.S., Gupta, N., Goh, K. and Umar, T., 2019. Potential regions in the GCC to deploy Off-Shore Floating Photovoltaic system-A better solution. Proceedings of the Institution of Civil Engineers-Energy, pp.1-19. https://doi.org/10.1680/jener.19.00061.

Honnurvali, M.S., Gupta, N., Goh, K., Umar, T., Kabbani, A. and Nazeema, N., 2018. Case study of PV output power degradation rates in Oman. IET Renewable Power Generation, 13(2), pp.352-360. https://doi.org/10.1049/iet-rpg.2018.5457.

Howarth, B., Khafaga, T., Simkins, G. and Joseph, S., 2019. Ecosystems as Commodity Frontiers - Challenges Faced by Land Set Aside as Protected Areas (PAs) in the Dubai Emirate, United Arab Emirates (UAE). In Commodity Frontiers and Global Capitalist Expansion (pp. 111-136). Palgrave Macmillan, Cham.

HSBC (Hongkong and Shanghai Banking Corporation), 2017. The Value of Education Higher and higher-UAE Report. HSBC, London, United Kingdom. See: https://www.hsbc.ae/1/PA_ES_Content_Mgmt/content/uae_pws/pdf/en/voe-report.pdf (accessed 19/11/2019). 
ICE member attributes, 2019. Attributes of Member and Chartered Civil Engineer (CEng MICE). Institution of Civil Engineers, London, United Kingdom. See: https://www.ice.org.uk/my-ice/membership-documents/member-attributes\#attributes of ceng (accessed 25/04/2019).

IEA (International Energy Agency), 2014. Electric power consumption (kWh per capita) United Arab Emirates. International Energy Agency, Paris, Fance. See: https://data. worldbank.org/indicator/EG.USE.ELEC.KH.PC?end=2014\&locations=AE\&start=19 71\&view=chart $($ accessed 25/09/2019).

IEA (International Energy Agency), 2016. Electricity generation by fuel United Arab Emirates 1990 - 2016. International Energy Agency, Paris, Fance. See:

https://www.iea.org//statistics/?country=UAE\&year=2016\&category=Electricity\&indicator=Elec GenByFuel\&mode $=$ chart $\&$ dataTable=ELECTRICITYANDHEAT $($ Accessed 25/09/2019).

IGBP (International Geosphere-Biosphere Programme), 1999. "Global Analysis, Integration and Modelling, "(IGBP, International Council of Scientific Unions, (ICSU), Durham, NH, 2000) http://gaim.unh.edu/; H. J. Schellnhuber, Nature 402, C19 (1999); National Research Council, Committee on Global Change Research, Global Environmental Change: Research Pathways for the Next Decade (National Academy Press, Washington, DC, 1999), p. 531, http://www.nap.edu/catalog/5992.html. (accessed 23/04/2019).

IRENA (International Renewable Energy Agency), 2019. Renewable Energy Market Analysis: GCC 2019. International Renewable Energy Agency, Abu Dhabi, United Arab Emirates. See: https://www.irena.org/publications/2019/Jan/Renewable-Energy-Market-Analysis-GCC2019 (accessed 21/11/2019).

ITA (International Trade Administration), 2019. United Arab Emirates - Oil and Gas Field Machinery and Services. International Trade Administration, U.S. Department of Commerce, Washington, DC, United States. See: https://www.export.gov/article?id=UnitedArab-Emirates-Energy-Power (accessed 24/11/2019).

Jabado, R.W., Al Ghais, S.M., Hamza, W. and Henderson, A.C., 2015. The shark fishery in the United Arab Emirates: an interview based approach to assess the status of sharks. Aquatic Conservation: Marine and Freshwater Ecosystems, 25(6), pp.800-816. http://dx.doi.org/10.1002/aqc.2477.

Jose, S. and Chacko, J., 2017. Building a sustainable higher education sector in the UAE. International Journal of Educational Management, 31(6), pp.752-765. https://doi.org/10.1108/ijem-05-2016-0102.

Kroll, C. 2015. Sustainable Development Goals - Are the rich countries ready? Gutersloh: Bertelsmann Stiftung. Gütersloh, Germany. See: https://www.bertelsmannstiftung.de/fileadmin/files/BSt/Publikationen/GrauePublikationen/Studie NW SustainableDevelopment-Goals_Are-the-rich-countries-ready_2015.pdf (accessed 27/04/2019).

Laffoley, D.D.A. and Baxter, J.M. eds., 2016. Explaining ocean warming: Causes, scale, effects and consequences. International Union for Conservation of Nature (IUCN), Gland, Switzerland. http://dx.doi.org/10.2305/IUCN.CH.2016.08.en. 
McIsaac, G.F. and Morey, N.C., 1998. Engineers' role in sustainable development: Considering cultural dynamics. Journal of Professional Issues in Engineering Education and Practice, 124(4), pp.110-119. https://doi.org/10.1061/(ASCE)1052-3928(1998)124:4(110).

MD:471 (Ministerial Decree No.471, 2016. Ministry of Climate Change and Environment Issues New Decree to Regulate Surface Fishing Using Beach Seines. Ministry of Climate Change and Environment, Dubai, United Arab Emirates. See:

MHP (Ministry of Health and Prevention), 2019. Medical Fitness Examinations and Certificates. Ministry of Health and Prevention. Abu Dhabi, United Arab Emirates. See: https://www.mohap.gov.ae/en/services/Pages/204.aspx (accessed 18/11/2019).

Michalak, A.M., 2016. Study role of climate change in extreme threats to water quality. Nature News, 535(7612), p.349. http://dx.doi.org/10.1080/19443994.2014.940649.

Moher D, Liberati A, Tetzlaff J, Altman DG, Prisma Group. Preferred reporting items for systematic reviews and meta-analyses: the PRISMA statement. PLoS medicine. $2009 \mathrm{Jul}$ 21;6(7):e1000097.

NCSDG (National Committee on Sustainable Development Goals), 2017. UAE and The 2030 Agenda For Sustainable Development, 2017. UAE and The 2030 Agenda For Sustainable Development, Minister of Foreign Affairs and International Cooperation, United Arab Emirates. See: https://sustainabledevelopment.un.org/content/documents/20161UAE SDGs Report Full Englis h.pdf (accessed 27/04/2019).

NFSS (National Food Security Strategy), 2019. National Food Security Strategy, Food Security Office, Duabi, United Arab Emirates. See: https://foodsecurity.gov.ae/ (accessed 17/11/2019).

Official Portal of the UAE Government, 2019. Road safety-Deaths and injuries from road traffic accidents, Official Portal of the UAE Government, Duabi, United Arab Emirates. See: https://www.government.ae/en/information-and-services/justice-safety-and-the-law/road-safety (accessed 18/11/2019).

ONS (Office for National Statistics), 2017. Energy: consumption from renewable and waste sources. Office for National Statistics, Newport, United Kingdom. See: https://www.ons.gov.uk/economy/environmentalaccounts/datasets/ukenvironmentalaccountsener gyconsumptionfromrenewableandwastesources (accessed 25/04/2019).

Opdenakker, R., 2006, September. Advantages and disadvantages of four interview techniques in qualitative research. In Forum Qualitative Sozialforschung/Forum: Qualitative Social Research (Vol. 7, No. 4).

PwC (PricewaterhouseCoopers), 2018. Education Sector in UAE-Understanding Middle East Education. PwC, Abu Dhabi, United Arab Emirates. See: https://www.pwc.com/m1/en/industries/education/education-country-profile-united-arabemirates.html (accessed 19/11/2019).

Reporters Without Borders, 2019. 2019 World Press Freedom Index. Reporters Without Borders, Paris, France. See: https://rsf.org/en/ranking (accessed 25/11/2019). 
Research and Markets, 2019. UAE Electric Vehicle Market (2019-2025): Market Forecast By Vehicle Types (Passenger Vehicle, Two-Wheeler, Bus and Truck), By Regions (Dubai, Abu Dhabi and Rest of Emirates) and Competitive Landscape. Research and Markets, Dublin, Ireland See: https://www.researchandmarkets.com/reports/4827883/uae-electricvehicle-market-2019-2025-

market?utm_source=CI\&utm_medium $=$ PressRelease\&utm_code=rl4f98\&utm_campaign=12892 13+-+UAE+Electric+Vehicle+Market+Report+2019-

2025+Featuring+BMW\%2c+GM\%2c+Groupe+Renault $\% 2 c+$ Hyundai $\% 2 c+$ Tesla\%2c+VW\&utm exec=chdo54prd $($ accessed 25/11/2019).

Sachs, J., Schmidt-Traub, G., Kroll, C., Durand-Delacre, D. and Teksoz, K. (2017): SDG Index and Dashboards Report 2017. Bertelsmann Stiftung and Sustainable Development Solutions Network (SDSN). New York, United States. See: http://sdgindex.org/assets/files/2017/2017-SDG-Index-and-Dashboards-Report--full.pdf (accessed 27/04/2019).

Sachs, J., Schmidt-Traub, G., Kroll, C., Durand-Delacre, D. and Teksoz, K. (2016): An SDG Index and Dashboards - Global Report. Bertelsmann Stiftung and Sustainable Development Solutions Network (SDSN). New York, United States. See: https://www.bertelsmannstiftung.de/fileadmin/files/BSt/Publikationen/GrauePublikationen/SDG_Index_Dashboard_full.pd

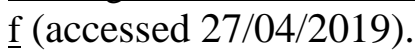

Sachs, J., Schmidt-Traub, G., Kroll, C., Lafortune, G., Fuller, G. (2019): Sustainable Development Report 2019. New York: Bertelsmann Stiftung and Sustainable Development Solutions Network (SDSN). See: https://s3.amazonaws.com/sustainabledevelopment.report/2019/2019 sustainable development $\mathrm{r}$ eport.pdf (accessed 21/09/2019).

Sachs, J., Schmidt-Traub, G., Kroll, C., Lafortune, G., Fuller, G. (2018): SDG Index and Dashboards Report 2018. New York: Bertelsmann Stiftung and Sustainable Development Solutions Network (SDSN). New York, United States. See: http://sdgindex.org/assets/files/2018/01\%20SDGS\%20GLOBAL\%20EDITION\%20WEB\%20V9 \%20180718.pdf (accessed 27/04/2019).

Sachs, J.D., 2015. The age of sustainable development. Columbia University Press, New York, United States.

Salahuddin, M. and Gow, J., 2014. Economic growth, energy consumption and CO2 emissions in Gulf Cooperation Council countries. Energy, 73, pp.44-58.

SDGIDR (Sustainable Development Goal Index and Dashboards Report), 2018. Sustainable Development Goal Index and Dashboards Report, Sustainable Development Solutions Network, United Nations, New York, USA. See: http://sdgindex.org/reports/2018/. (accessed 27/04/2019).

Strabac, Z., Valenta, M., \& Al Awad, M. (2018). Temporary labour migration to United Arab Emirates: a complex story. Migration and Development, 7(3), 352-365. https://doi.org/10.1080/21632324.2017.1421603.

Swain, S., 2018. Construction Wastes Management in the UAE. Eco-MENA, Doha, Qatar. See: ecomena.org/construction-waste-uae/ (accessed 25/09/2019). 
TGE (The Green Economy), 2012. The Green Economy initiative, Green Economy for Sustainable Development. The Official Portal of the United Arab Emirates. See: https://government.ae/about-the-uae/economy/green-economy-for-sustainable-development (accessed 28/04/2019).

The National, 2018. Dubai Ruler launches Marmoom Desert Conservation Reserve. The National, Abu Dhabi, United Arab Emirates. See:

https://www.thenational.ae/uae/environment/dubai-ruler-launches-marmoom-desert-conservationreserve-1.696015 (accessed 25/11/2019).

TSDGR (The Sustainable Development Goals Report), 2018. The Sustainable Development Goals Report, United Nations, New York, United States. See:

https://unstats.un.org/sdgs/files/report/2018/TheSustainableDevelopmentGoalsReport2018EN.pdf (accessed 25/04/2019).

UAE-CA (UAE contractors Association), 2019. Member list. UAE contractors Association, Duabi, United Arab Emirates. See: http://uaecontractors.org/members list pdf/MEMBER LIST 2017.pdf (accessed 21/09/2019).

UAEES (United Arab Emirates Energy Strategy 2050). UAE Energy Strategy, 2050. The Official Portal of the UAE Government, United Arab Emirates. See: https://government.ae/en/about-the-uae/strategies-initiatives-and-awards/federal-governmentsstrategies-and-plans/uae-energy-strategy-2050 (accessed 29/04/2019).

UAEGA (United Arab Emirates Green Agenda: 2015-2030), 2015. United Arab Emirates Green Agenda: 2015-2030. United Arab Emirates. See: http://www.lse.ac.uk/GranthamInstitute/law/uae-green-agenda-2015-2030/ (accessed 28/04/2019).

UAE-Labour Law, 1980. U.A.E. LABOUR LAW FEDERAL LAW NO. (8) OF 1980 Ministry of Human Resources and Emiratisation, Abu Dhabi, United Arab Emirates. See: https://www.mohre.gov.ae/en/laws-legislation/labour-law.aspx (accessed 17/11/2019).

UAESDG (United Arab Emirates Sustainable Development Goals), 2019. The UAE portal for the Sustainable Development Goals, Dubai, United Arab Emirates. See: http://uaesdgs.ae/en (accessed 24/04/2019).

Umar, T. and Egbu, C., 2018-a. Global commitment towards sustainable energy. Proceedings of the Institution of Civil Engineers-Engineering Sustainability (pp. 1-9). Thomas Telford Ltd. https://doi.org/10.1680/jensu.17.00059.

Umar, T. and Egbu, C., 2018-b. Heat stress, a hidden cause of accidents in construction. Proceedings of the Institution of Civil Engineers-Municipal Engineer (pp. 1-12). Thomas Telford Ltd. https://doi.org/10.1680/jmuen.18.00004.

Umar, T. and Egbu, C., 2018-c. Perceptions on safety climate: a case study in the Omani construction industry. Proceedings of the ICE-Management, Procurement and Law, 171(6), pp.251-263. https://doi.org/10.1680/jmapl.18.00001.

Umar, T. and Wamuziri, S., 2016. Briefing: Conventional, wind and solar energy resources in Oman. Proceedings of the Institution of Civil Engineers-Energy, 169(4), pp.143-147. https://doi.org/10.1680/jener.16.00011. 
Umar, T. and Wamuziri, S., 2017. Briefing: Using 'safety climate factors' to improve construction safety. Proceedings of the Institution of Civil Engineers-Municipal Engineer (Vol. 170, No. 2, pp. 65-67). Thomas Telford Ltd. https://doi.org/10.1680/jmuen.16.00020.

Umar, T., (2019). Developing Toolkits and Guidelines to Improve Safety Performance in the Construction Industry in Oman. PhD thesis. London South Bank University, London, UK.

Umar, T., 2017-a. Briefing: Cost of accidents in the construction industry of Oman. Proceedings of the Institution of Civil Engineers-Municipal Engineer (Vol. 170, No. 2, pp. 68-73). Thomas Telford Ltd. https://doi.org/10.1680/jmuen.16.00032.

Umar, T., 2017-b. Rooftop solar photovoltaic energy: a case study of India. Nanomaterials and Energy, 6(1), pp.17-22. https://doi.org/10.1680/jnaen.16.00002.

Umar, T., 2017-c. Briefing: Defining safety leadership in construction. Proceedings of the Institution of Civil Engineers-Municipal Engineer (Vol. 170, No. 1, pp. 3-5). Thomas Telford Ltd. https://doi.org/10.1680/jmuen.16.00004.

Umar, T., 2018-a. Geothermal energy resources in Oman. Proceedings of the Institution of Civil Engineers-Energy, 171(1), pp.37-43. https://doi.org/10.1680/jener.17.00001.

Umar, T., 2018-b. Briefing: Towards a sustainable energy: the potential of biomass for electricity generation in Oman. Proceedings of the Institution of Civil Engineers-Engineering Sustainability (Vol. 171, No. 7, pp. 329-333). Thomas Telford Ltd. https://doi.org/10.1680/jensu.17.00001.

Umar, T., 2018-c. Causes of delay in construction projects in Oman. Middle East Journal of Management, 5(2), pp.121-136. https://doi.org/10.1504/MEJM.2018.091132.

Umar, T., Egbu, C. and Saidani, M., 2019-c. A Modified Method for Los Angeles Abrasion Test. Iranian Journal of Science and Technology, Transactions of Civil Engineering, pp.1-7. https://doi.org/10.1007/s40996-019-00268-w.

Umar, T., Egbu, C., Honnurvali, M.S., Saidani, M. and Al-Bayati, A.J., 2019-b. Briefing: Status of occupational safety and health in GCC construction. Proceedings of the Institution of Civil Engineers-Management, Procurement and Law, 172(4), pp.137-141. https://doi.org/10.1680/jmapl.18.00053.

Umar, T., Egbu, C., Ofori, G., Honnurvali, M.S., Saidani, M., and Opoku, A. 2019-d. Reducing Greenhouse Gas (GHG) Emissions from Municipal Solid Waste in Oman. Proceedings of the Institution of Civil Engineers-Municipal Engineer. https://doi.org/10.1680/jmuen.19.00027.

Umar, T., Egbu, C., Ofori, G., Honnurvali, M.S., Saidani, M., and Opoku, A. 2019-a. Challenges towards renewable energy: an exploratory study from the Arabian Gulf region.

Proceedings of the Institution of Civil Engineers-Energy. https://doi.org/10.1680/jener.19.00034. 
Umar, T., Egbu, C., Wamuziri, S. and Honnurvali, M.S., 2018. Briefing: Occupational safety and health regulations in Oman. Proceedings of the Institution of Civil EngineersManagement, Procurement and Law, 171(3), pp.93-99. https://doi.org/10.1680/jmapl.18.00007.

UNFCC (United Nations Framework Convention on Climate Change), 1992. United Nations Framework Convention on Climate Change, New York, United States. See: https://unfccc.int/resource/docs/convkp/conveng.pdf (accessed 23/04/2019).

UN-SDG (United Nations Sustainable Development Goals), 2015. About the Sustainable Development Goals. United Nations, New York, United States. See: https://www.un.org/sustainabledevelopment/sustainable-development-goals/ (accessed 23/04/2019).

Villacorte, L.O., Tabatabai, S.A.A., Dhakal, N., Amy, G., Schippers, J.C. and Kennedy, M.D., 2015. Algal blooms: an emerging threat to seawater reverse osmosis desalination. Desalination and Water Treatment, 55(10), pp.2601-2611. http://dx.doi.org/10.1038/535349a.

WB (The World Bank), 2018. Logistics Performance Index (LPI) - Global Rankings 2018. The World Bank, Washington, D.C., United States. See: https://lpi.worldbank.org/international/global/2018 (accessed 23/11/2019).

WB (World Bank), 2014-a. Electric power consumption (kWh per capita). The World Bank, Washington, D.C., United States. See: https://data.worldbank.org/indicator/EG.USE.ELEC.KH.PC?end=2014\&name_desc=fals e\&page=2\&start=2014\&view=map\&year=2014 (accessed 18/04/2019).

WB (World Bank), 2014-b. $\mathrm{CO}_{2}$ emissions (metric tons per capita). The World Bank, Washington, D.C., United States. See: https://data.worldbank.org/indicator/en.atm.co2e.pc?year_high_desc=true (accessed 18/04/2019).

WB (World Bank), 2017. PM2.5 air pollution, mean annual exposure (micrograms per cubic meter). The World Bank, Washington, D.C., United States. See: https://data.worldbank.org/indicator/en.atm.pm25.mc.m3 (accessed 24/11/2019).

WB (World Bank), 2019. What A Waste Global Database. The World Bank, Washington, D.C., United States. See: https://datacatalog.worldbank.org/dataset/what-waste-global-database (accessed 21/01/2020).

WBLGB (World Bank's Little Green Book), 2017. The Little Green Data Book. The World Bank, Washington, D.C., United States. See: http://datatopics.worldbank.org/worlddevelopment-indicators/themes/environment.html (accessed 21/01/2020).

WEC (World Energy Council), 2018. Country Profile: United Arab Emirates. World Energy Council, London, United Kingdom. See: https://trilemma.worldenergy.org/\#!/countryprofile? country=United\%20Arab\%20Emirates\&year=2018 (accessed 29/04/2019).

WEF (World Economic Forum), 2018. The Global Gender Gap Report-2018. World Economic Forum, Cologny, Switzerland. See: http://www3.weforum.org/docs/WEF GGGR 2018.pdf (accessed 20/11/2019). 
WEF (World Economic Forum), 2018. This is how to sustainably feed 10 billion people by 2050. World Economic Forum, Cologny, Switzerland. See: https://www.weforum.org/agenda/2018/12/how-to-sustainably-feed-10-billion-people-by-2050in-21-charts/ (accessed 23/04/2019).

WHO (World Health Organization), 2018. Ambient (outdoor) air pollution. World Health Organization, Geneva, Switzerland. See: https://www.who.int/news-room/factsheets/detail/ambient-(outdoor)-air-quality-and-health (accessed 20/01/2020).

WHO (World Health Organization), 2016. Global Health Observatory data repository, Annual mean concentration of particulate matter of less than 2.5 microns of diameter (PM2.5) [ug/m3] in urban areas. World Health Organization, Geneva, Switzerland. See: http://apps.who.int/gho/data/node.main.152?lang=en (accessed 29/04/2019).

WJPI (World Justice Project Index), 2019. WJP Rule of Law Index 2019. World Justice Project Index, Washington DC, United States. See: http://data.worldjusticeproject.org/ (accessed 25/11/2019).

WPR (World Population Review), 2019. United Arab Emirates Population 2019. World Population Review - online. See: http://worldpopulationreview.com/countries/united-arabemirates-population/ (accessed 17/11/2019).

WSS (Water Security Strategy, 2036), 2017. The UAE Water Security Strategy 2036. The Official Portal of the UAE Government, United Arab Emirates. See: https://government.ae/en/about-the-uae/strategies-initiatives-and-awards/federal-governmentsstrategies-and-plans/the-uae-water-security-strategy-2036 (accessed 28/04/2019).

Zafar, S., 2015. Solid Waste Management in Saudi Arabia. EcoMENA, March 28. http://www.ecomena.org/solid-waste-management-in-saudi arabia/. (accessed 24/04/2018).

Zafar, S., 2018. Waste Management Outlook for the Middle East. In The Palgrave Handbook of Sustainability (pp. 159-181). Palgrave Macmillan, Cham, Basingstoke, United Kingdom.

Zawaya, 2017. UAE turns aluminum waste into alternative energy. Zawaya, Muscat, Oman. See: https://www.zawya.com/mena/en/business/story/UAE turns aluminum waste into alternative e nergy minister-ZAWYA20171213102919/ (accessed 28/04/2019).

Zyoud, S.H., S.W. Al-Jabi, W.M. Sweileh, S. Al-Khalil, S.H. Zyoud, A.F. Sawalha, and R. Awang. 2015. The Arab world's Contribution to Solid Waste Literature: A Bibliometric Analysis. Journal of Occupational Medicine and Toxicology 10 (35), 1-9. 